\title{
Investigating cattle husbandry in the Swiss Late Neolithic using different scales of temporal precision: potential early evidence for deliberate livestock "improvement" in Europe
}

\author{
Elizabeth Wright ${ }^{1}$ (D) \\ Received: 16 June 2020 / Accepted: 1 December 2020 / Published online: 30 January 2021 \\ (C) The Author(s) 2020
}

\begin{abstract}
Cattle were the most common domestic livestock animal throughout much of the Neolithic period in the area now occupied by modern day Switzerland, home to a significant number of sites dating to between approximately 4400 and $2500 \mathrm{cal}$ BC. Many of these sites were located in wetland locations, resulting in very well-preserved large faunal assemblages which can be dated using dendrochronology with rare precision. This region is also particularly important for our knowledge of the spread of culture and innovation through Central Europe during the Neolithic period-its topography results in a natural corridor through which influences travelled from both the east and west. This study is the first to combine cattle data from across the whole of Switzerland, focusing on \%NISP and biometrical data, in order to investigate how cattle husbandry changed over time, comparing the east and west of the region. A number of different temporal scales are used in order to look for broad patterns and then focus in for more detail. Results indicate that there is a clear correlation between \%NISP and body size of cattle throughout much of the Swiss Neolithic and that cattle husbandry changed broadly in line with perceived cultural changes in both the east and west. Of particular interest is a clear increase in both \%NISP and body size around the time of the introduction of the Corded Ware culture, contrary to the general pattern of cattle body size decrease seen across Europe at this time. This change is seen, however, in the west of Switzerland prior to the east and raises questions around alternative origins and areas of influence. Either way, the most likely explanation for the increase in cattle size is the introduction of a new population (or populations) of larger cattle into the region, which are incorporated into herds over a few hundred years, providing perhaps some of the earliest evidence for cattle "improvement" in Europe.
\end{abstract}

Keywords Late Neolithic $\cdot$ Cattle $\cdot$ Husbandry $\cdot$ Switzerland $\cdot$ Body size $\cdot \%$ NISP

\section{Introduction}

Switzerland is home to a large number of Late Neolithic sites dating to between $\mathrm{c} 4400$ and $2500 \mathrm{cal} \mathrm{BC}{ }^{1}$. A high proportion of these sites are located in wetland environments, pri-

\footnotetext{
${ }^{1}$ In this paper "Late Neolithic" refers to the time period made up of what is known as the "Jungneolithikum", "Spätneolithikum" and Endneolithikum" in Swiss archaeology. Chronology tables for the Neolithic period in Switzerland can be found in Jacomet (2007) and Schibler (2013).
}

Elizabeth Wright

Elizabeth.wright@unibas.ch

1 Integrative Prehistory and Archaeological Science (IPAS), University of Basel, Basel, Switzerland marily situated on lake shores, and as a result have excellent organic preservation, producing large, well-preserved zooarchaeological and archaeobotanical assemblages. These sites have also regularly yielded wood which has been used to date settlement layers precisely using dendrochronology, sometimes to within decades or even years. Additionally, the position of Switzerland and its topography is highly significant for our knowledge of the spread of ideas during the Neolithic period. The Alps in the south east of the country and the Jura to the north west create a topographic corridor running from the north east to the south west, linking Central Europe to the Mediterranean, through which cultural influence could have travelled in both directions (Fig. 1). Evidence from material culture, for example, has suggested that eastern Switzerland was more influenced by the cultures 


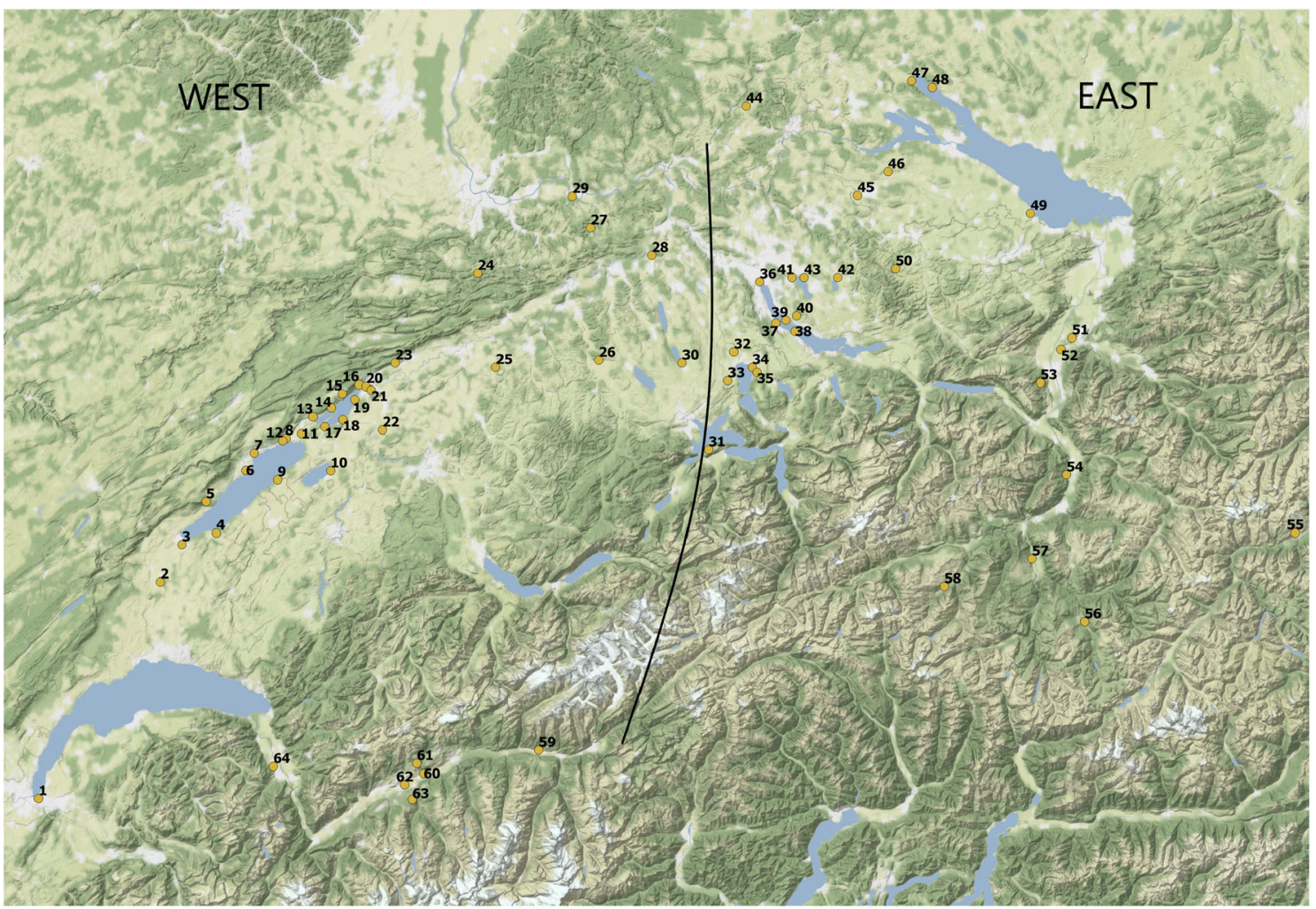

Fig. 1 Map of sites included in this study. The line indicates which sites were included in the western group (on the left) and the eastern group (to the right) for analysis

of Central Europe, and western Switzerland was more influenced by the cultures of the Mediterranean region during this time (Stöckli et al. 1995).

The combination of these factors provide an excellent opportunity to study the organic assemblages from these sites looking at relatively fine time slices, in order to inform our knowledge about the spread of agricultural innovation through Central Europe at the time. This paper presents some results from the first zooarchaeological study to combine all available \%NISP and biometrical cattle data from Swiss Neolithic sites, using time slices at different scales of precision in order to track changes in cattle husbandry through time.

\section{Hunting and animal husbandry as part of the Late Neolithic economy in Switzerland}

A large amount of work has been undertaken on zooarchaeological assemblages from Swiss Late Neolithic sites over the last 40 years, with much of this being completed at the Institute of Integrative Prehistory and Archaeological Science (IPAS) at the University of Basel. Remains of both wild and domesticated animals were deposited at these sites, and wild animals make up particularly high proportions of faunal assemblages especially before $3400 \mathrm{cal}$ BC, with red deer the most common hunted species across the whole region (Hüster-Plogmann et al. 1999a; Schibler 2006; Schibler and
Jacomet 2010; Schibler 2017). The importance of hunting fluctuates during this time, however, with peaks in hunting activity thought to be related to short-term climatic fluctuations (Arbogast et al. 2006; Schibler 2006; Schibler et al. 1997a; Schibler and Jacomet 2010). Past work has concentrated extensively on the role of red deer, which is one reason for the focus on domestic livestock in this work.

Domestic livestock animals, cattle, pigs and caprines, also played an important role throughout the Late Neolithic period. Cattle were on average the most common domestic livestock species, although there were fluctuations in their importance in relation to other species through time (see below). In earlier periods, between c4300 and $4000 \mathrm{cal} \mathrm{BC}$, caprines seem to have had a relatively high importance, particularly in areas of western Switzerland such as the Rhone valley, which is thought to be related to a combination of a strong Mediterranean influence and topography (Schibler 2006). After this, caprines tend to be less prevalent, particularly in eastern Switzerland, until around the time of the introduction of Corded Ware from around $2800 \mathrm{cal} \mathrm{BC}$ where proportions start to increase again, up to quite high levels in the Bronze Age. This is thought to be related to the introduction of a new kind of sheep for wool production at this time (Schibler 1997).

Pigs were more regularly present across the whole Late Neolithic period than caprines and seem to have been of particular importance during the Horgen period between c3400 
and $2800 \mathrm{cal} \mathrm{BC}$, where they are represented by higher proportions of faunal remains than cattle at settlements across the whole of Switzerland (Schibler 2006). This change in economic focus seems to have been more acute and have begun earlier in eastern Switzerland than in the west. Proportionally pigs then decrease in importance from 2800 cal BC onwards, although bone density data (see Schibler et al. 1997a, 1997b) suggests that this pattern is mainly due to an increase in the proportion of cattle remains at this time, and that pig herds continued to be a similar size (Schibler 2006).

\section{Cattle in Late Neolithic Switzerland}

Both domestic and wild cattle were exploited in Switzerland during the Late Neolithic period. However, aurochs tend to be present in relatively small numbers and did not seem to play a very large part in subsistence practices at most sites (HüsterPlogmann et al. 1999b). There are a few exceptions to this, however, particularly prior to $3400 \mathrm{cal} \mathrm{BC}$, such as at the sites around the lake of Burgäschisee, in central Switzerland, where aurochs remains are particularly prevalent (Boessneck et al. 1963; Stampfli 1964; Schäfer and Schibler, In Prep.). At these sites, aurochs are particularly common during periods of high levels of hunting activity, thought to be related to the climatic fluctuations previously mentioned above (Arbogast et al. 2006; Schibler 2006; Schibler et al. 1997a; Schibler and Jacomet 2010).

The majority of cattle remains at Swiss Late Neolithic sites, therefore, belong to domestic cattle. Four phases of domestic cattle husbandry have previously been defined, which broadly follow cultural changes (Schibler 2006, 2017). These broad phases will form the basis of the analysis in this paper:

\section{1. $4300-4000 \mathrm{cal}$ BC (referred to with the code LNI in this paper)}

During this period, very low percentages of cattle remains are found in faunal assemblages, with caprines and pigs more prevalent, as well as red deer. It has been suggested that only very small cattle herds were kept at this time, and that the focus was on meat production, due to the high frequency of younger individuals (Hüster-Plogmann and Schibler 1997).

2. $4000-3400$ cal BC (referred to with the code LNII in this paper)

During this phase, which is roughly concurrent with the Cortaillod and Pfyn cultures, cattle seem to increase in importance, and are present in much higher proportions than in the preceding period (Hüster-Plogmann and Schibler 1997; Schibler 2006, 2017). It is thought that cattle first started being used for secondary products, such as milk and labour, during this period, with direct evidence for the use of milk being found using organic residue analysis on pot sherds from the site of Arbon Bleiche, dated to around 3400 cal BC (Spangenberg et al. 2006), and early evidence for traction being found at the same site (Deschler-Erb and Marti-Grädel 2004).

3. $3400-2800$ cal BC (referred to with the code LNIII in this paper)

Proportions of cattle then reduce during the following period, which coincides broadly with the Horgen culture. This pattern is due to an increase in the importance of pigs at this time, as cattle find densities remain at a similar level to the preceding period. Biometrical evidence has indicated that cattle became smaller and potentially more robust during this period, which is thought to have been linked to their use for labour (Hüster-Plogmann and Schibler 1997).

4. $2800-2500$ cal BC (referred to with the code LNIV in this paper)

The final phase, which is broadly concurrent with the influence of Corded Ware culture in eastern Switzerland and at Auvernier Cordé sites in the west, is characterised by much higher proportions (and bone densities) of cattle remains, thought to indicate the expansion of cattle herds, and a correlated increase in body size (Arbogast et al. 2006; Schibler 2006). This period also has the first evidence for castrates, supporting specialised cattle use for traction (HüsterPlogmann and Schibler 1997). Carbon isotope results on cattle remains suggest a clearly reduced forest cover in the Zurich region between early 4 th and the 2 nd Millennium BC, which coincides broadly with the introduction of Corded Ware to the region (Doppler et al. 2017) and correlates with the zooarchaeological evidence for the expansion of cattle herds and ploughing.

\section{Previous investigations of cattle body size and shape in Late Neolithic Switzerland}

Despite the amount of zooarchaeological work that has been undertaken on Swiss Neolithic cattle remains, the issue of body size change on a regional or national scale has been relatively understudied. This is part due to the fact that most zooarchaeological work in Switzerland is undertaken as part of canton-funded projects focusing on individual sites or groups of excavations, which do not generally have the scope for wider ranging analyses. Some work investigating the change in body size of domestic species was undertaken in the 1960 s by Charles Higham (1968a, 1968b), who noted a general decrease in size of cattle during the Neolithic period, but his work focused on a relatively small number of sites and was 
undertaken prior to the large-scale excavations which produced much of the faunal data that we now work with. More recently, after new excavations in the 1980s and 1990s, material from the Zurich region was studied (Hüster-Plogmann and Schibler 1997). This work confirmed the general size decrease trend, and highlighted the small size of cattle present in the Horgen period, along with an increasing robusticity evident in the phalanges of cattle from these layers (Hüster-Plogmann and Schibler 1997). Additionally, however, a size increase was then seen at the end of this period, more or less concurrent with the arrival of the Corded Ware culture (HüsterPlogmann and Schibler 1997). These broad patterns in the Zurich region have also been compared to those from contemporary sites in the French Jura, which indicate a broadly similar pattern, with cattle becoming very small and then much larger again from around $2900 \mathrm{cal}$ BC (Arbogast et al. 2006). This previous work sets an important framework, but the original work on the Zurich region is now more than 20 years old. Since it was undertaken, a number of new sites in this area have been excavated, and more data have also been collected and analysed from other areas of Switzerland. This is the first study bringing together all of the available data from all regions, and studying this dataset at such a fine scale.

\section{Material and methods}

\section{Material}

NISP (Number of Identified Specimens) and measurement data were collected from Late Neolithic sites across the area now occupied by modern day Switzerland (Fig. 1). Data from Bronze Age sites were also collected, but precise chronological data were not available for many of the assemblages, so they have only been presented briefly here. Material from 246 layers across 88 sites was suitable for inclusion in the analysis. More than 300 layers are included in the project database, but not all of these were suitable for inclusion because of dating issues. Not all layers yielded both NISP and measurement data, but a layer was included if it yielded either. In this study, the focus is on postcranial measurements, because these provided more consistent sample sizes and reliable comparable data. Although they were not analysed, tooth data were recorded and are included in the project database (Wright et al. 2020).

A substantial proportion of the dataset was retrieved from databases held at IPAS at the University of Basel, where a large proportion of Swiss prehistoric assemblages have been studied over the last 40 years. Additionally, data were collected from the literature, and two assemblages (Zug Sennweid and Zurich Versicherung) were revisited by the author in order to take measurements.

\section{Methodology}

$\%$ NISP and biometrical data were chosen for this analysis as they are most easily comparable across studies undertaken by different researchers. In previous work bone find density (see Schibler et al. 1997a and 199b) has been presented alongside \%NISP, in order to provide further information on the importance of livestock animals (e.g. Schibler 2017, 2013, 2006), but this information was not consistently available across all sites. It would have also been useful to include age-at-death information in order to get a more holistic view of animal husbandry; however, there are differences in the ways in which these data are recorded, and comparable analysis across a large enough number of sites was not possible. Comments on bone density information and mortality patterns from the original publications are included in the discussion section.

Combining data from numerous sources should be undertaken with caution due to the different collection and counting methodologies employed by different researchers. NISP, for example, is often counted slightly differently by different people, and different levels of identification are employed, particularly regarding species with both wild and domestic forms, such as cattle and pigs, or species with very close morphology such as sheep and goats. As a result, an attempt has been made to standardise the data across all datasets, by combining all wild and domestic cattle and pig specimens into "Bos" and "Sus" categories and all sheep and goats into a "Caprines" category for analysis. This is of course slightly problematic when the aim is to focus on cattle as part of the domestic economy, because wild specimens are also included in these groups, but it was the only way to standardise data that has been recorded and identified in a variety of different ways. This issue is dealt with by presenting the NISP and biometrical information together, so that the potential impact of wild individuals in each sample can be included as part of the analysis. As the analysis also only focusses on the three main groups (Bos, Sus and Caprines), this study therefore excludes evidence from red deer, which was very common at Swiss Late Neolithic sites. As such the \%NISP values reported in this paper are those from Bos, Sus and Caprines in relation to each other only (see Supplementary Table S1 for raw counts).

For measurements, widely used standardised methodologies make these data relatively easy to compare. The majority of measurements included in this project were taken according to von den Driesch (1976) or was described as being taken in exactly the same way. The benefits of having a large dataset were seen to outweigh the potential issues introduced due to "Observer Error", as the majority of measurements were taken by members of the same team in Basel who work together 
closely, and previous studies investigating this issue on archaeological material detected relatively low levels of error (Davis 1996; Johnstone 1999; Popkin et al. 2012).

Similarly to the approach for NISP, all Bos measurements were combined into one Bos group, rather than attempting to split the sample between Bos taurus and Bos primigenius. This was done for two reasons - firstly, it allowed for a more direct comparison with the \%NISP results, but secondly, it acknowledges the difficulties of separating wild and domestic Bos remains (Degerbøl and Fredskild 1970; von den Driesch and Boessneck 1976; Wright 2016). Further discussion of this issue can be found in the discussion of the results in Section 3.

Measurements were analysed using a log ratio index scaling technique (Meadow 1999; Simpson et al. 1960). This technique involves the comparison of measurements from a dataset to that of a standard individual or population, by calculating what is known as the log size index (LSI). Through this, multiple different measurements can be combined on the same scale, and sample sizes can be enhanced. The technique can be described using this basic formula LSI $=\log _{10}(x / y)$, where $x$ is the value of the archaeological specimen and $y$ is the standard of that same measurement calculated from the standard population. In this study a standard individual was used from the reference collection at IPAS. This was a 13year-old modern Hinterwälder female (Z-2431) (Breuer et al. 1999).

The measurements included in this analysis were chosen using these main criteria:

1. Their availability in databases and reports (generally linked to their prevalence in assemblages due to taphonomic processes, etc.).

2. The ease with which they can be taken consistently by different researchers.

3. The potential information that each measurement can provide - very age dependent measurements (such as scapula SLC, for example) were excluded for the analysis, even though they are recorded in the database.

4. An appropriate standard measurement for comparison was available

Table 1 lists the measurements included in the log ratio analysis. Only one measurement per bone per dimension was selected in order to avoid repeating data from the same individual, and measurements are listed in their order of priority. Length and width measurements have been presented separately in the analysis in order to see any differences between the two dimensions. Depth measurements were not recorded consistently across enough sites and have therefore not been included. The list of sites and the appropriate references are included in Table S2 of the supplementary Material. The
Table 1 Measurements included in the log ratio analysis, in order of priority

\begin{tabular}{lll}
\hline Element & \multicolumn{2}{l}{$\begin{array}{l}\text { Measurements } \\
\text { (following von den Driesch 1976) }\end{array}$} \\
\cline { 2 - 3 } & Lengths & Widths \\
\hline Humerus & GL & Bd, BT, Bp \\
Radius & GL & BFd \\
Metacarpal & GL & Bd \\
Femur & GL & Bp \\
Tibia & GL & Bd, Bp \\
Metatarsal & GL & $\mathrm{Bd}$ \\
Astragalus & GLl, GLm & $\mathrm{Bd}$ \\
Calcaneum & GL, & GB \\
\hline
\end{tabular}

project database containing all of the raw data are published in an open-access database (Wright et al. 2020).

Log ratio results are presented using box plots and also histograms in order to see the distribution of measurements within each time slice and to investigate the impact of sexual dimorphism and the presence of aurochs within the distributions. For the broad cultural phases, where the largest samples are available, log ratio histograms showing individual measurements on selected bones have also been presented, in order to investigate these issues more thoroughly. Histograms displaying raw measurements are also available in the Supplementary Material (Figs. S1, S2, S3, S4, S5, S6), where appropriate histograms have been annotated with the location of males, females and wild and domestic groups. Where possible, the variation between different chronological and geographical groups seen in the log ratio results has been tested statistically using a Mann-Whitney $U$ test $(p \leq 0.05)$. Additionally, effect size has been calculated in order to account for the practical significance of the Mann-Whitney results.

Some samples were fairly small, especially when considering material from very narrow time slices. All samples were retained in the \%NISP plots, box plots and histograms, and the sample sizes marked, so that the reader can visually see the gaps and their reliability. For \%NISP, samples of less than 100 were considered to be unreliable at the interpretation stage, and are mentioned as such. For the biometrical results, samples of less than 20 were treated with caution at the interpretation stage, and Mann-Whitney tests and effect size calculations were only performed on samples of 20 or more.

Data analysis was undertaken using $\mathrm{R}$ ( $\mathrm{R}$ Core Team 2020), using the packages dplyr (Wickham et al. 2020) and reshape 2 for organising the data, ggplot2 (Wickham 2016) for creating the charts, and gridExtra (Auguie 2017) for the chart arrangements. 


\section{Chronology}

The dataset includes both wetland and dryland sites, which have been dated using ${ }^{14} \mathrm{C}$ dating, dendrochronology, stratigraphy or a combination of these. In some cases, wetland sites were dated using dendrochronology with a very fine temporal precision of just a couple of decades, and the intention has been to use this precision as much as possible. Dryland site dating tends to rely on a combination of ${ }^{14} \mathrm{C}$ dating and stratigraphic information, and so less precision is possible. As a result, in order to have large enough sample sizes for the biometrical study and include datasets from both wetland and dryland sites, chronological groups at four levels of precision have been used in the analysis (Fig. 2). The first groups are based on broad cultural phases that have been defined in the Swiss Late Neolithic ${ }^{2}$. These are referred to using the codes LNI, LNII, LNII and LNIV. Bronze Age data have also been included in this diagram so that the longer term trends can be seen. The second scale splits the data into 300-year intervals, the third into 200-year intervals, and the final most precise scale uses 100-year intervals. These time slices use the original LN codes as a reference, and then each 100 years within each code period has a letter, e.g. LNII-ABC for 300 years, LNII-AB for 200 years and LNII-A for 100 years. Splitting the data according to these intervals allows for as much of the data as possible to be used, depending on the dating information available for each site. It also allows one to look for patterns in the data using slightly different groupings.

NISP data at very fine levels of precision (on a layer by layer basis) have been presented and analysed elsewhere (e.g. Schibler 2006, 2017), but have not previously been directly combined with and compared to the body size data.

\section{Geography}

The datasets have been divided into two groups representing western and central (referred to as "western" for the rest of this paper), and eastern Switzerland, respectively (see Fig. 1 for how the region has been split). This is based on the hypothesis that during the Neolithic period, there were different influences impacting these different parts of the region, with the east more influenced by Central European practices, and the west more influenced by Mediterranean practices, as mentioned above (Stöckli et al. 1995). Of course there may have

\footnotetext{
$\overline{2 \text { Archaeological }}$ cultural groups, such as "Cortaillod", "Pfyn", "Horgen" and "Corded Ware" are used throughout this paper for analytical purposes, but it is important to remember that the use of these categories can be misleading and problematic. Not only do they imply that influences were uniform across the whole of Switzerland at the same time, which is not the case, but they can impact the way in which we interpret our data by forcing our narratives in certain directions. For a discussion of this issue in relation to the Swiss Neolithic see (e.g.) Gross (2017).
}

been other aspects at play within these broad areas, at a subregional or topographical level, but sample sizes became very small at the precise levels of temporal precision required for this study when data were split further. Another paper, currently in preparation, will present the analysis of data at a smaller regional level, using just the broad culturally based chronological groupings described above.

\section{Results}

NISP and biometry box plot results have been aligned and presented using the above described four time scales, and histograms have been presented alongside, so that the distribution of measurements can be seen. For the broadest periods with the largest samples sizes extra histograms presenting the $\log$ ratio results by bone and measurement have been included Figs. 3, 4, 5 and 6 use broad cultural groups, Figs. 8 and $9300-$ year intervals, Figs. 10 and 11 200-year intervals and Figs. 12 and 13 100-year intervals.

\section{Broad cultural groups: $4400-800$ cal BC (Figs. 3, 4, 5, 6 and 7)}

Figure 3 provides data from both the Neolithic and Bronze Age using broad cultural-based groups, with \%NISP at the top, and the corresponding log ratio box plots underneath. Figure 4 shows the biometrical results on histograms so that the distribution of individual measurements can be more easily seen. Both \%NISP and body size results show a broadly similar pattern in both the west and east, with a correlated decrease in both the proportion and size of cattle between LNII (broadly correlated with the Cortaillod and Pfyn Cultures) and LNIII (broadly correlated with the Horgen period) and then an increase in both proportion and body size going into the final Neolithic period (LNIV-corresponding broadly to the Corded Ware and related Auvernier Cordé cultures). These body size changes are all highly significant ( $p \leq$ 0.01 ) according to the results of the Mann-Whitney $U$ tests; however, not all have a moderate or large effect sizes. In the east, the change between LNIII and LNIV has a moderate effect size for both length and width measurements, suggesting that this change is more reliable than between LNII and LNIII, where effect sizes are small. In the West, none of the effect sizes is moderate or large. In the Bronze Age, there seems to be a stabilisation in the prevalence of cattle in both areas, whilst in the east, body size decreases during the Bronze Age, with the largest effect sizes seen between LNIV and the MBA and LBA. The small amount of data from the west indicates that a similar pattern may be present here, but sample sizes are very small.

There are a few differences between the east and west. Cattle seem to be present in higher proportions in general 


\begin{tabular}{|c|c|c|c|c|c|c|c|c|c|c|c|c|c|c|c|c|c|c|c|}
\hline \multirow{4}{*}{$\begin{array}{l}\text { Broad Phase } \\
300 y \text { Phase } \\
200 y \text { P Phase } \\
100 y \text { P Phase }\end{array}$} & \multirow{2}{*}{\multicolumn{4}{|c|}{$\begin{array}{c}\text { LNI } \\
\text { PRE-CORTAILLOD } \\
\text { LNI-ABCD }\end{array}$}} & \multicolumn{6}{|c|}{$\begin{array}{c}\text { LNII } \\
\text { CORTAILLOD/PFYN }\end{array}$} & \multicolumn{6}{|c|}{$\begin{array}{c}\text { LNIII } \\
\text { HORGEN }\end{array}$} & \multirow{2}{*}{\multicolumn{3}{|c|}{$\begin{array}{c}\text { LNIV } \\
\text { CORDED WARE } \\
\text { LNIV-ABC }\end{array}$}} \\
\hline & & & & & \multicolumn{3}{|c|}{ LNII-ABC } & \multicolumn{3}{|c|}{ LNII-DEF } & \multicolumn{3}{|c|}{ LNIII-ABC } & \multicolumn{3}{|c|}{ LNIII-DEF } & & & \\
\hline & \multicolumn{4}{|c|}{ LNI-ABCD } & \multicolumn{2}{|c|}{ LNII-AB } & \multicolumn{2}{|c|}{ LNII-CD } & \multicolumn{2}{|c|}{ LNII-EF } & \multicolumn{2}{|c|}{ LNIII-AB } & \multicolumn{2}{|c|}{ LNIII-CD } & \multicolumn{2}{|c|}{ LNIII-EF } & \multicolumn{2}{|c|}{ LNIV-AB } & LNIV-C \\
\hline & LNI-A & LNI-B & LNI-C & LNI-D & LNIII-A & LNIII-B & LNII-C & LNIII-D & LNII-E & LNIIIF & LNIII-A & LNIII-B & LNIII-C & LNIII-D & LNIIIE & LNIII-F & LNIV-A & LNIV-B & LNIV-C \\
\hline
\end{tabular}

Fig. 2 Timeline and time slices used for analysis

across time in the east than in the west, where caprines are slightly more common. This fits with the previous findings that caprines were of particular importance in western areas due to the Mediterranean connection (Schibler 2006). There are also some slight differences in the body size data, where the increase in size going into LNIV is more acute in the east than in the west, with the median (in the box plots) and mean (in the histograms) of both length and width measurements landing above the standard " 0 " line in the east but below in the west. This is reflected in the results of the Mann-Whitney test where length measurements in the west show a slightly less highly significant result than width measurements when the samples from LNIII and LNIV are compared; however, it is worth bearing in mind that neither of these shows a moderate or large effect size.
Fig. $3 \%$ NISP and log ratio box plots for the broadest scale analysis. Dates for the Bronze Age are early Bronze Age, 2200 1600 cal BC; Middle Bronze Age, 1600-1300 cal BC; and Late Bronze Age, $1300-800$ cal BC

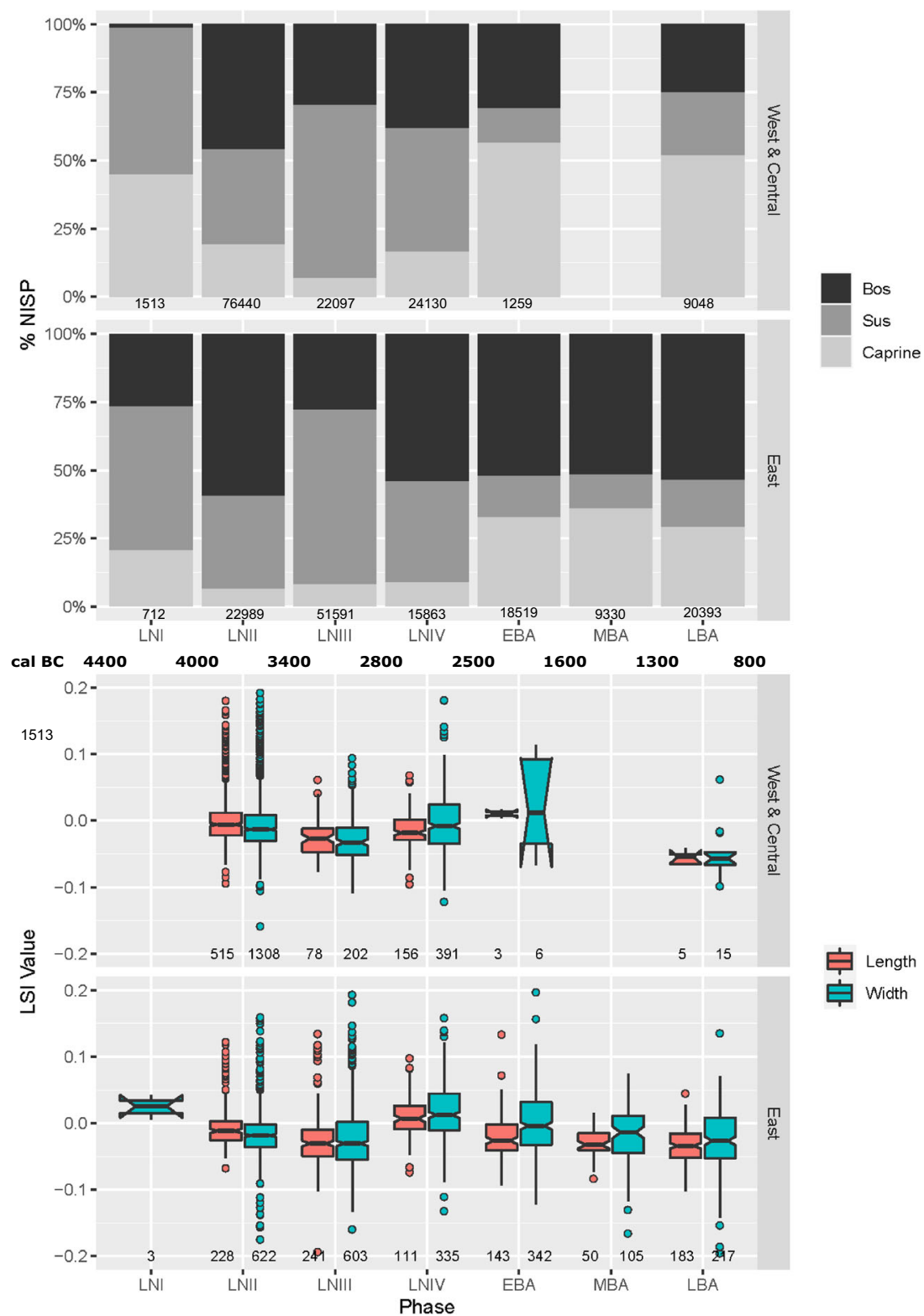




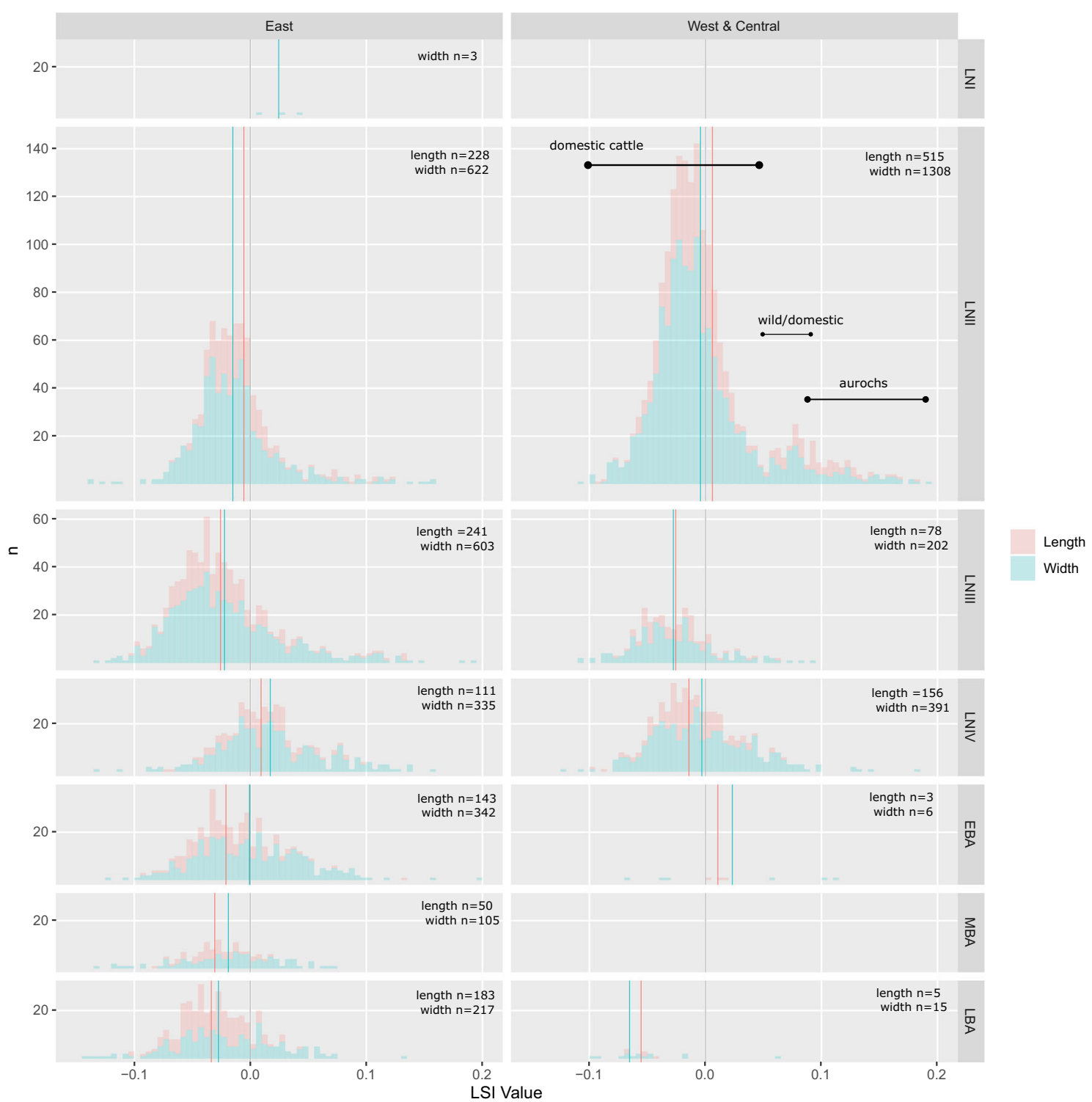

Fig. 4 Log ratio histograms showing the distribution of measurements for each broad time slice. The areas on the plot where likely aurochs and domestic cattle are placed is marked. The standard is indicated with a black line, and length and width means indicated with red and green lines respectively. On one plot the location of likely wild, domestic and unclear individuals has been marked to demonstrate where their distributions lie
The impact of sexual dimorphism and the presence of aurochsen were also investigated. In order to do this, further log ratio plots were created, splitting the data by bone and showing the distribution of individual measurements (Figs. 5 and 6). Histograms displaying raw measurements for selected bones are also included in the Supplementary Information (Figs. S1, S2, S3, S4, S5, S6). Metapodial measurements, and particularly metacarpal breadth measurements, are most useful for investigating sex groups (Fig. 5), and the distribution of $\mathrm{Bd}$ measurements in both indicates that females probably outnumbered males in most if not all Late Neolithic periods, with the peak towards the smaller end of the scale. This indicates that size changes cannot be explained by large shifts in the sex ratios within cattle herds. Scatterplots are possible only on a Switzerland-wide basis (i.e. combining east and west samples together), in order to look at shape as well as size, and consider the potential impact of castrates (Fig. 7). Metacarpals and metatarsals from the three main Neolithic phases were compared. The metacarpal results confirm that seen in the histograms - females tend to dominate in all three phases. It is also clear that in both metacarpals and metatarsals, length and width measurements increase at a similar rate between the Horgen and Corded Ware periods, and that there is no clear change in shape that might indicate that castrates were greatly impacting the pattern.

It is clear that aurochs were quite prevalent in LNII, and the likely areas in which domestic and wild individuals appear have been marked on the histograms (Figs. 4, 5 and 6). It 
Fig. 5 Log ratio histograms showing just metapodial bones by measurement. On one of the metapodial plots, the likely male and female groups have been marked to demonstrate where their distributions lie
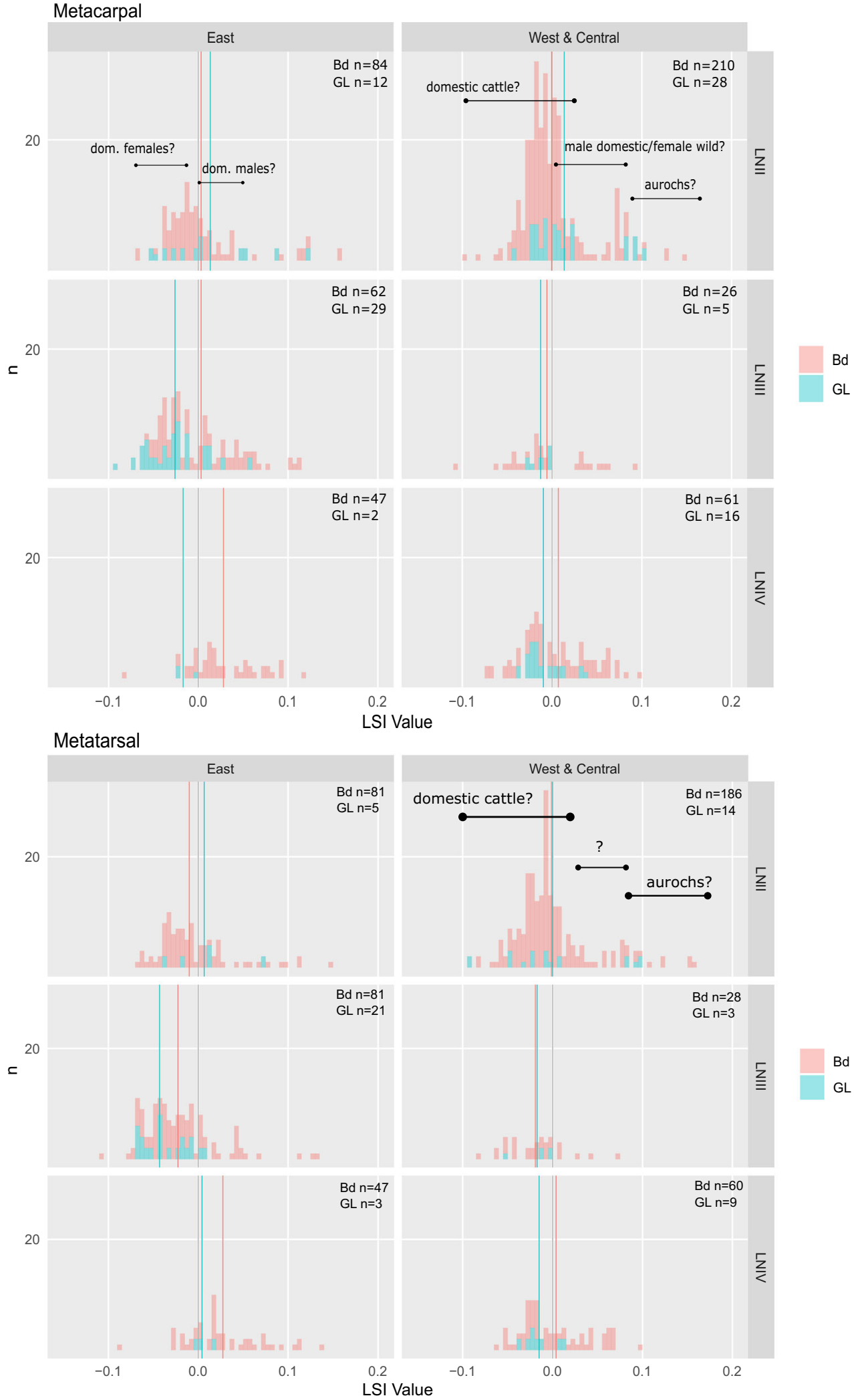

seems likely that any data point higher than 0.1 on the plots probably represents aurochs, and many of the individuals appearing at less than 0.05 are likely to be domestic cattle, but the exact division is not clear, particularly for breadth measurements. Length measurements are easier to separate, but with the exception of the astragalus, and perhaps the 

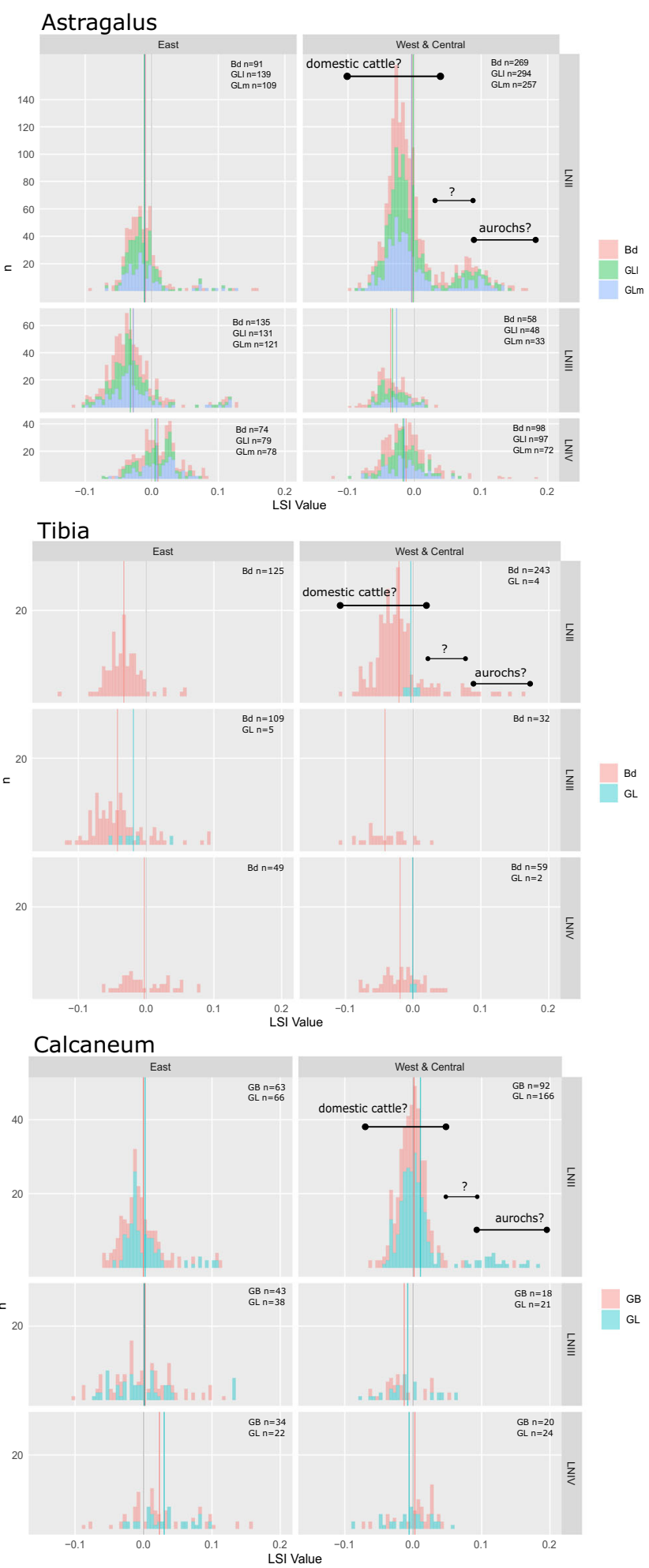

Fig. 6 Log ratio histograms showing the astragalus, tibia and calcaneum individually by measurement. The location of likely wild, domestic and unclear individuals has been marked to demonstrate where their distributions lie

metapodials in some regions and periods, samples are relatively small. After LNII, aurochs do not disappear completely, but it looks likely that they are not affecting the patterns and statistics considerably. Although a small number of aurochsen are likely present in the LNIII and LNIV distributions, the fact that a size increase between the two phases can be seen amongst the smallest individuals on each plot indicates that the overall size increase is taking place independently of this.

The individual measurement plots also highlight that the broad pattern of size changes can be seen across all elements and is not solely led by the domination of elements such as the astragalus. Of particular note is the lack of correlation between length and width measurements seen in metapodials in LNIII at eastern sites (Fig. 5), with the mean of length measurements plotting far lower on the plot than the standard skeleton, compared to the mean of width measurements, indicating that these bones were fairly short and robust. This seems to confirm that evidence previously reported from phalanges on the robusticity (as mentioned in section 1.3) of these short cattle is reliable (Hüster-Plogmann and Schibler 1997). Although a similar pattern can be seen on a few of the other diagrams, length measurements tend to have such small samples that these results are not reliable. This includes the sample sizes for the west at this time, so it is not possible to say for sure if this pattern existed in the same way there.

\section{0-year interval groups: $4400-2500 \mathrm{cal}$ BC}

The remainder of the diagrams only concentrate on the Neolithic period, as chronological precision is not available from most Bronze Age sites. Histograms by individual measurements are also not provided for the finer time slices, as samples get fairly small; however it is still possible to use the combined diagrams to look for the presence of aurochs within the distributions, based on the work undertaken for the broad periods above.

Figures 8 and 9 show the results using 300-year intervals (with the exception of LNI-ABCD which contained very few data and combines 400 years). In these diagrams, LNII and LNIII are split into early and later groups. From the beginning of the LNII-ABC until midway through LNII-ABC, both east and west show very similar patterns in terms of \%NISP, with proportions of cattle reducing over time.

At first glance, looking at the box plots (Fig. 8), west and east are showing very different body size patterns during LNII-ABC, with much larger cattle in the west than the east, particularly according to length measurements, which show a highly significant Mann-Whitney result $(p \leq 0.001)$ and a moderate effect size for lengths. However, this pattern can be explained by the likely high proportion of aurochs in the western sample, which is highlighted in the histograms (Fig. 9). The histograms also show a smaller number of aurochs in the east at the time, as well as in LNII-DEF in both regions.

The reduction in the proportion of cattle between LNIIDEF and LNIII-ABC is reflected in both the east and west 


\section{Metacarpals}
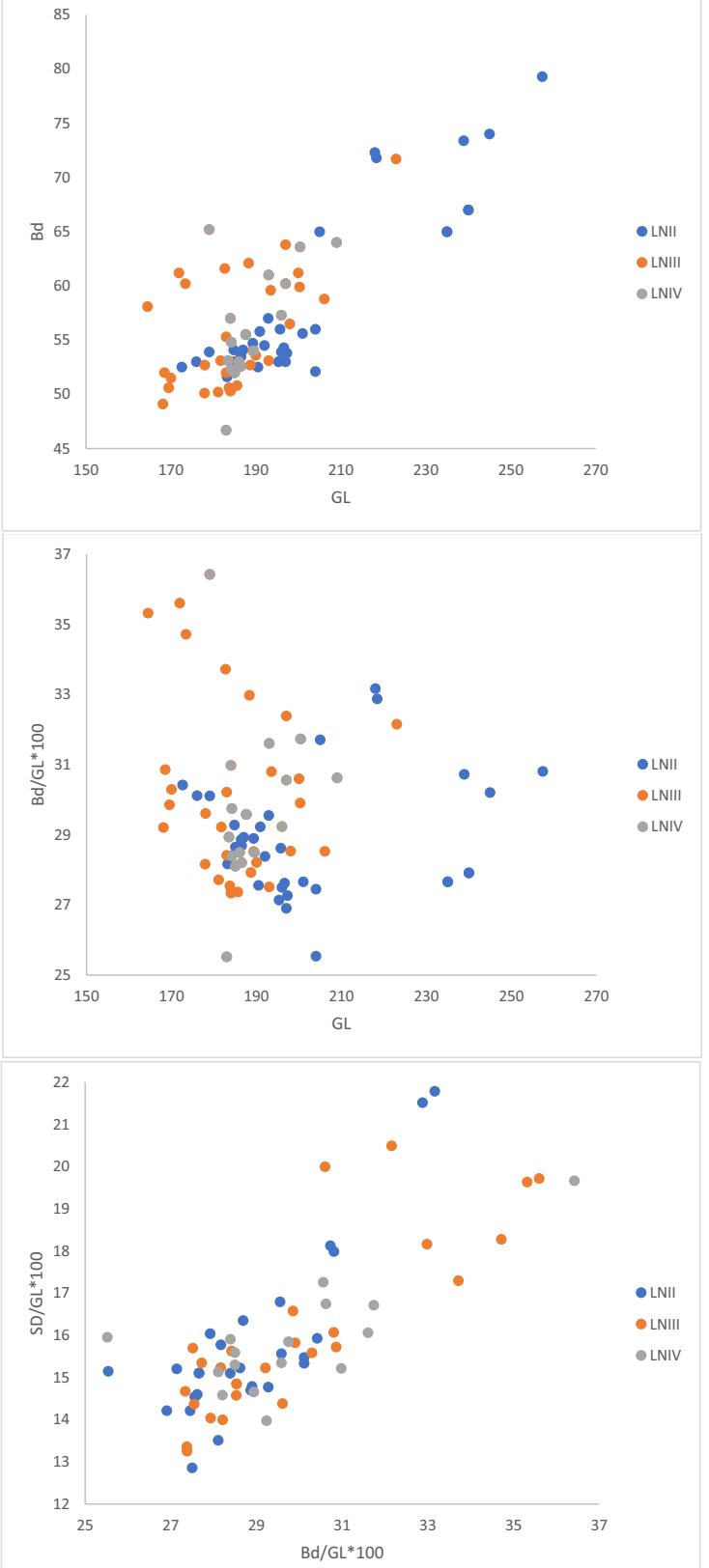

Fig. 7 Scatterplots for metapodial measurements for the broad phases

of Switzerland by a correlating reduction in body size, confirmed to be very highly significant in both lengths and widths by the Mann-Whitney $U$ test results, and with a moderate effect size on eastern lengths. This reduction in size is taking place in both regions, even though it looks like there are probably a few aurochs in the distribution in the east at this time. However, the two geographical areas show different patterns for LNIII-DEF, with the west showing both an increase in $\%$ NISP and body size, and the east seeing a further reduction in both. Although it is possible that a small number of aurochs could be influencing the pattern in the west, there are no individuals above the 0.1 line, which indicates that these are very

\section{Metatarsals}
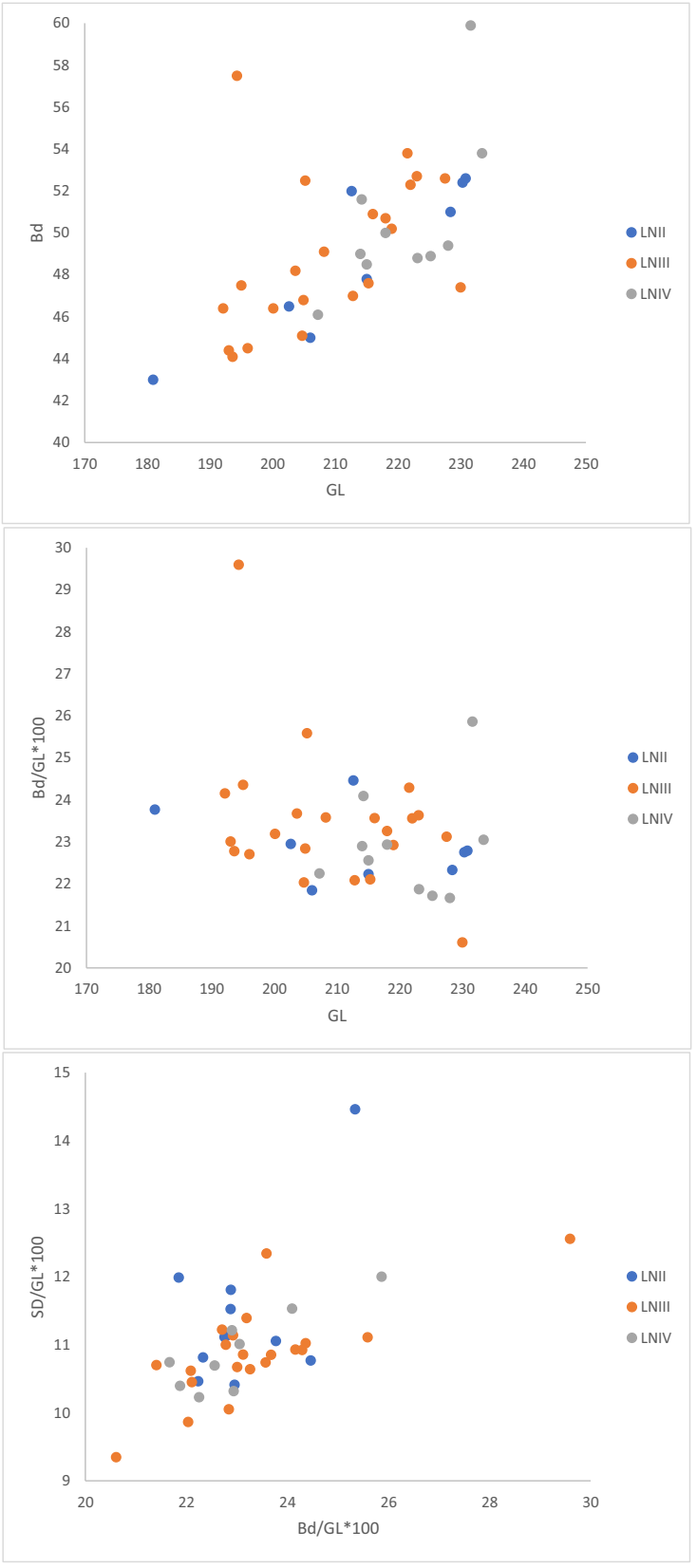

few. These changes are subtle, however, and the only statistically significant difference is seen between widths between these two periods in the east $(p=0.0223)$, and this is with a small effect size. In both the east and west, \%NISP and size are correlated, but there is a small amount of evidence that they are experiencing slightly different processes.

Both the east and west show an increase in cattle size between LNIII-DEF and LNIV-ABC, despite a drop in the proportion of cattle in the west- this is the first time that the NISP and body size data do not correlate with each other. A much larger jump is seen in the east (demonstrated by more highly significant results in the Mann-Whitney tests for both lengths 
Fig. $8 \%$ NISP and log ratio box plots with 300-year time slices

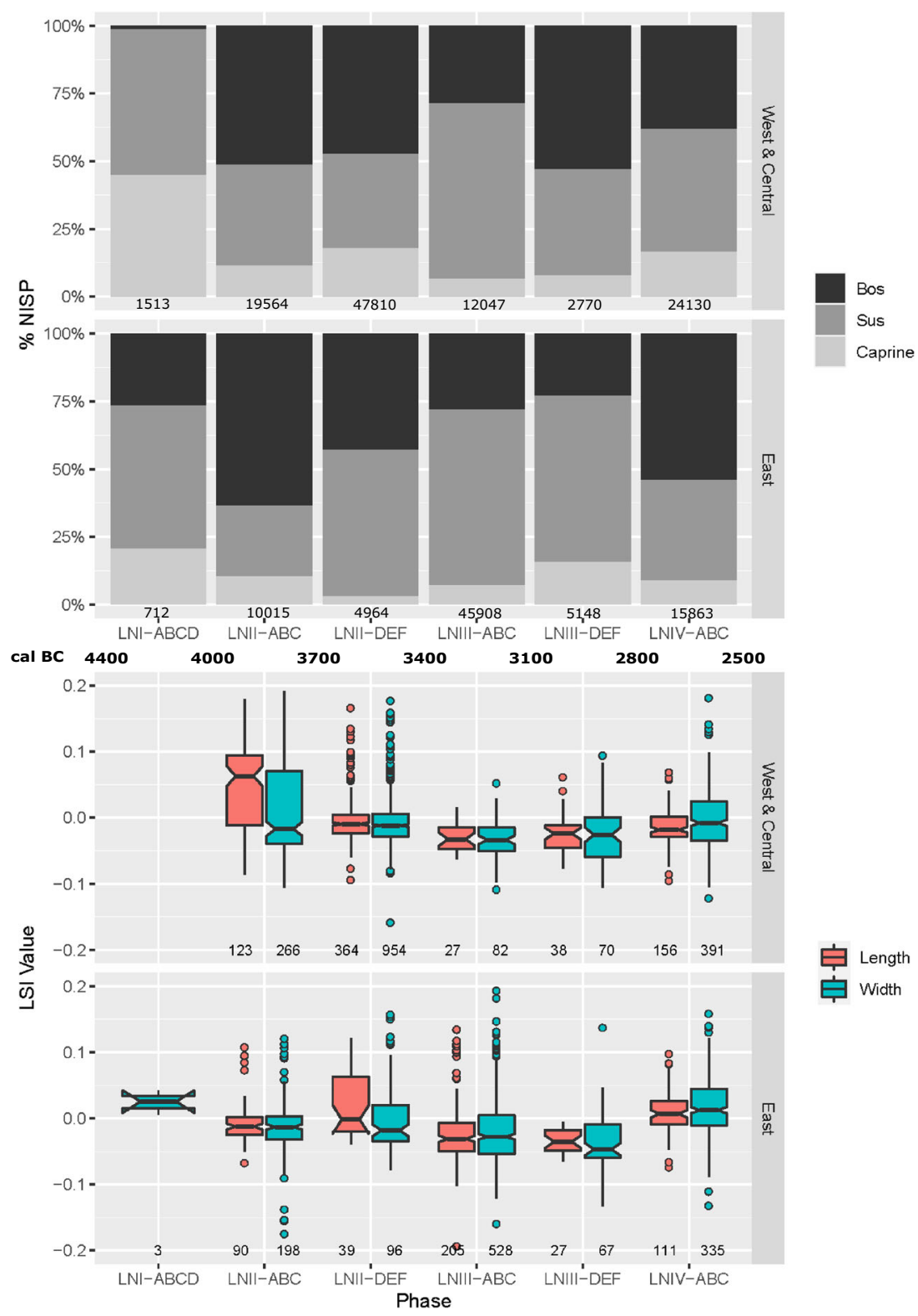

and widths, and large effect size for lengths and moderate for widths). This is in part due to the fact that size in the west had already started increasing in LNIII-DEF but also because the average size of cattle in the east during LNIV-ABC was larger than in the west (both length and width measurements are above the standard here, whereas both are below in the west). The difference between body size in LNIV-ABC in the east and west is confirmed by the high statistical significance between these two groups in the Mann-Whitney test and a moderate effect size seen for length measurements. It is possible that a small number of aurochs may be included in the distributions from both regions, but the shift in size is also seen at the smallest end of the scale, indicating that a shift is taking place within the domestic population.
Presenting the data using 300-year intervals confirms the general correlation between \%NISP and body size for cattle in both the east and west of Switzerland but highlights some potential differences at the transition between the second half of the Horgen and Corded Ware period, where \%NISP in the West drops off, whilst body size continues to increase.

\section{0-year interval groups: 4000-2500 cal BC}

When broken down into 200-year slices (Figs. 10 and 11), we can see a little clearer how the previous patterns have been composed. LNI has been excluded here as it contained very few data. LNII and LNIII are now split into three groups each 


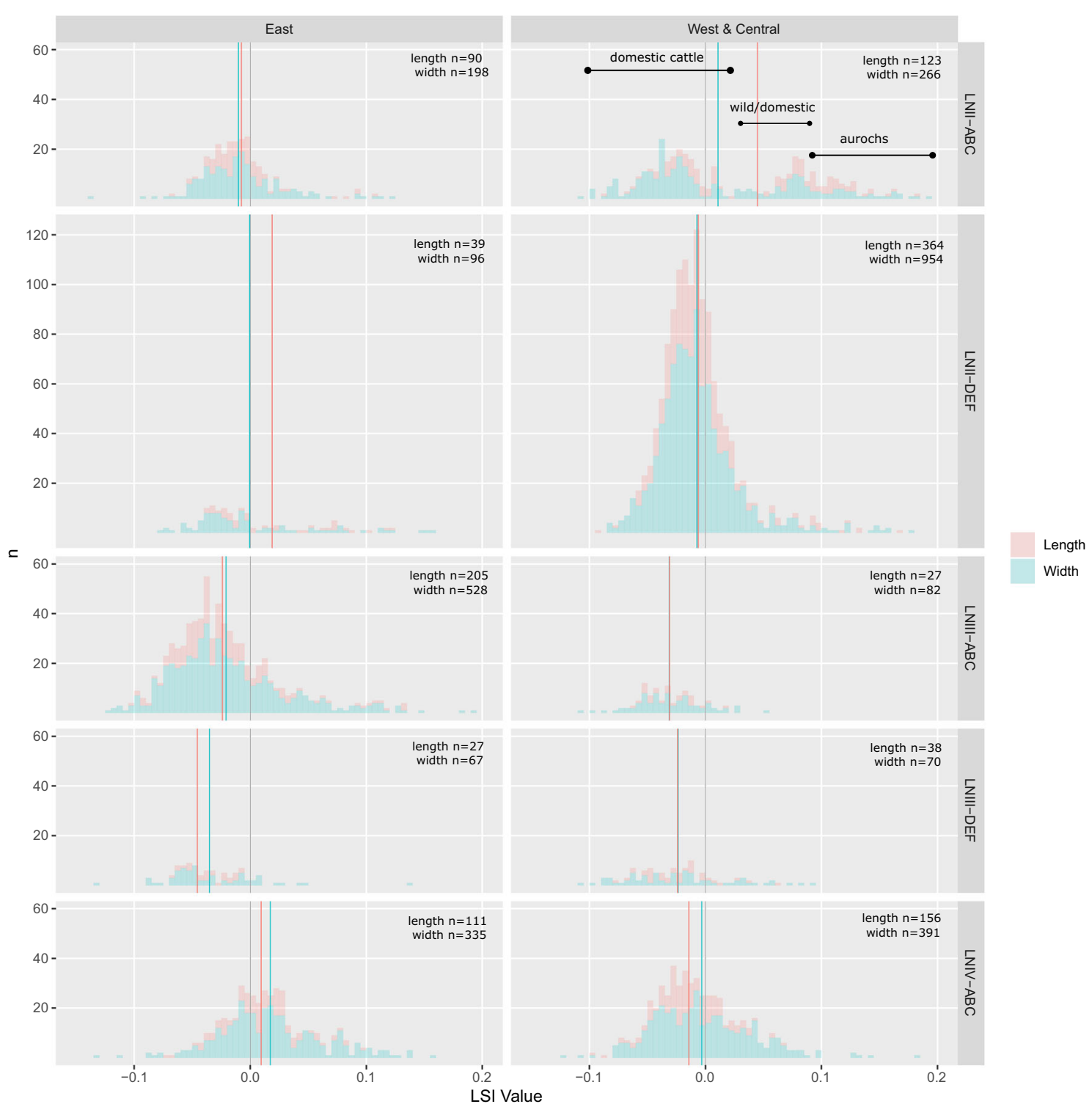

Fig. 9 Log ratio histograms showing the distribution of measurements for each 300-year time slice. The standard is indicated with a black line, and length and width means indicated with red and green lines, respectively.

On one plot the location of likely wild, domestic and unclear individuals has been marked to demonstrate where their distributions lie

and LNIV into two. As this final broad phase is only 300 years long, the final group (LNIV-C) is made up of just 100 years.

In both the east and west, LNII-AB and LNII-CD show relatively high proportions of cattle, which clearly include a number of aurochs remains, which can be seen in the histograms, particularly in LNII-CD (Fig. 11). The differences in \%NISP between east and west during LNII-EF suggests that the proportion of pigs may have increased in the east earlier than in the west, although the eastern sample has a very small sample size $(n=89)$ which is not reliable.

Both areas show good correlation between \%NISP and body size in the first two phases of LNIII, with a reduction in both, despite the fact that there are clearly a small number of aurochs in the distribution. In both the east and west, cattle reach their smallest body size in LNIII-CD, between 3200 and $3000 \mathrm{cal} \mathrm{BC}$, although this drop is more acute in the east than the west. In LNIII-EF, both \%NISP and body size increase in both the east and the west, although this pattern is clearest and most reliable in the west (as demonstrated by both the MannWhitney and effect size results) where cattle reach their highest \%NISP before dropping off into LNIV, where proportions of both pigs and caprines increase again. The east sees higher proportions of cattle slightly later, during LNIV-AB from $\mathrm{c} 2800 \mathrm{cal} \mathrm{BC}$, and remains at a high level until the end of LNIV-C at $2500 \mathrm{cal}$ BC. In both the east and west, cattle remain at a large size until the end of LNIV, but in the east, body size is larger on average overall. The highest effect sizes 
Fig. $10 \%$ NISP and log ratio box plots with 200-year time slices

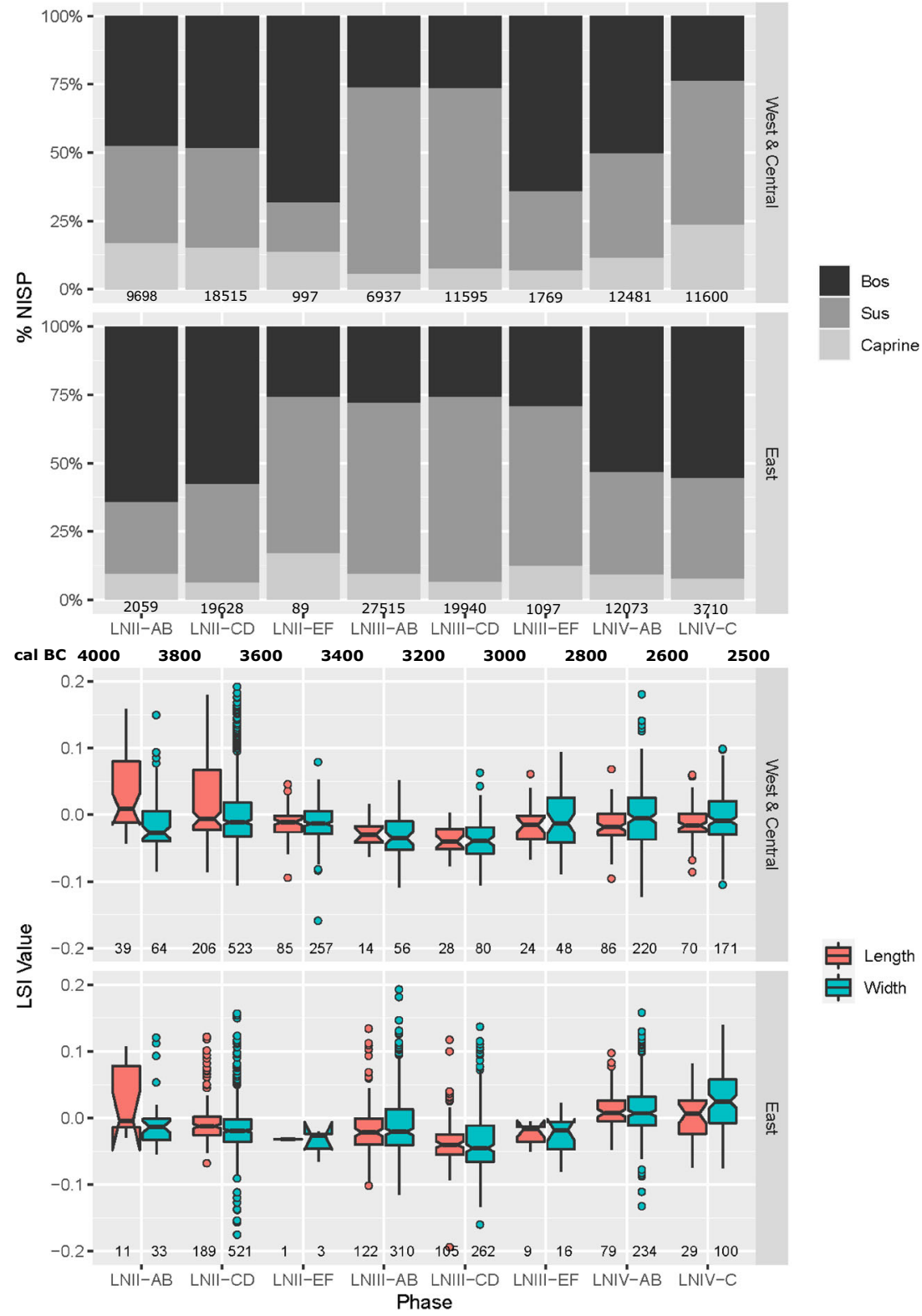

are seen in the east comparing LNIII-CD to both time slices within LNIV, demonstrating that the size change which took place sometime between 3000 and 2800 BC is truly significant. Differences between east and west during this period are confirmed by the highly significant Mann-Whitney results for both widths and lengths in both LNIV time slices and the moderate effect sizes seen in LNIV-AB lengths and LNIV-C widths.

\section{0-year interval groups: $4000-2500 \mathrm{cal} \mathrm{BC}$}

\section{$\%$ NISP and box plots}

The 100-year plots (Figs. 12 and 13) break the pattern down into even finer temporal groups, across the same timespan as used for the 200-year interval groups. Unsurprisingly, this has an impact on the sample size for both \%NISP and body size. Still, it is clear that enough of the time slices have a large enough sample to be able to follow the pattern through time, albeit with some gaps.

During LNII, the periods in which aurochs are prevalent are now even clearer, with particularly high numbers present between LNII-B and LNII-D (3900-3600), and particularly in the west. After this in the west, there are very few individuals with a $\log$ ratio value of above 0.1 , which indicates that very few aurochs are included in the plots. In the east, there do seem to be more larger individuals, with the main concentration in LNIII-A. At around this time (c3400 cal BC), the pattern changes drastically, as expected from the previous plots, with cattle being pushed to $30 \%$ or lower of the $\%$ NISP, in 


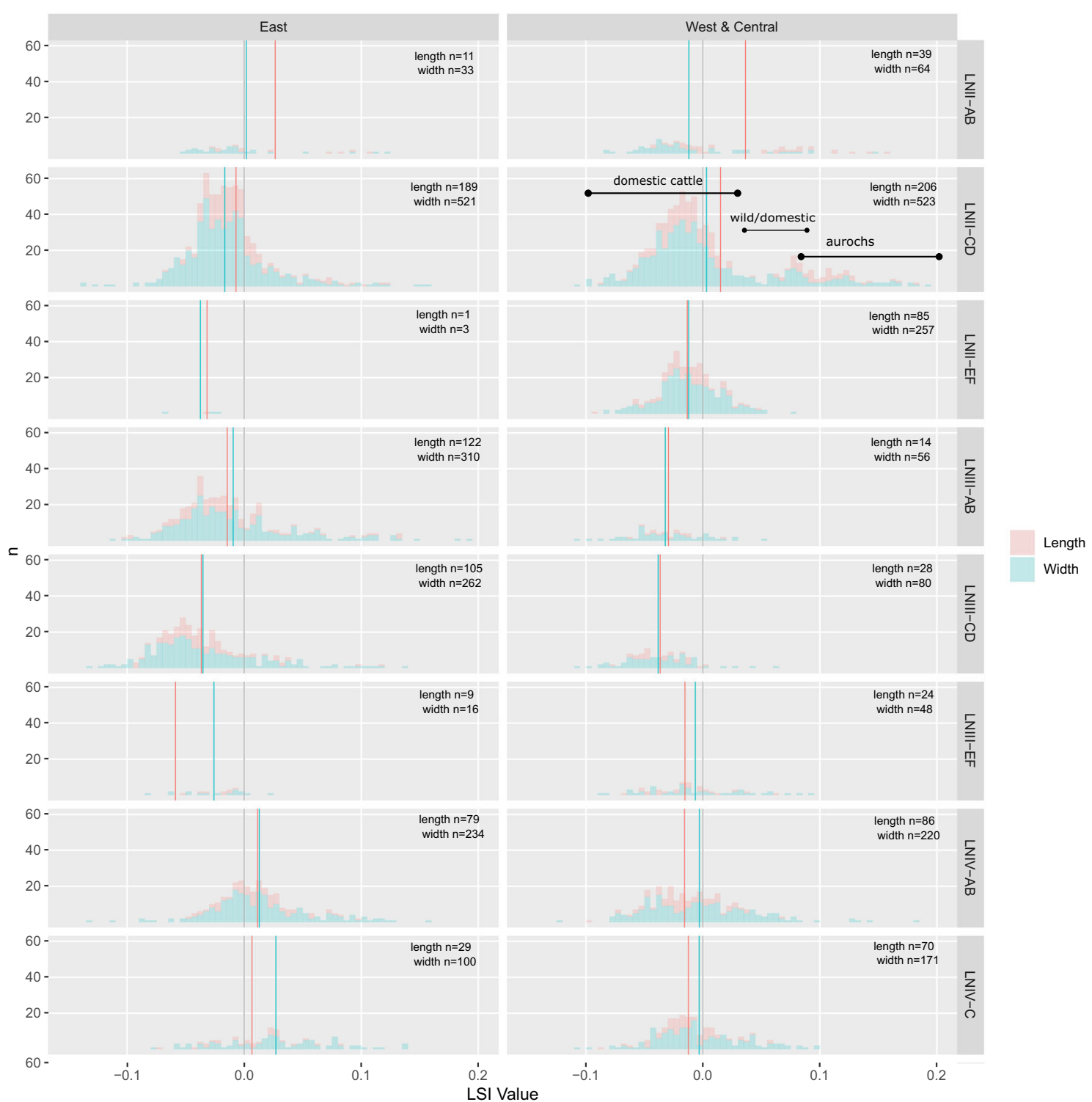

Fig. 11 Log ratio histograms showing the distribution of measurements for each 200-year time slice. The standard is indicated with a black line, and length and width means indicated with red and green lines

respectively. On one plot the location of likely wild, domestic and unclear individuals has been marked to demonstrate where their distributions lie

particular by the increase in the proportion of pig bones, where it stays for the majority of this period in both the east and west until approximately $3000 \mathrm{cal}$ BC. In both areas, cattle are at their smallest size between 3200 and 3000 cal BC, as seen previously in the 200-year plot. In the east, the largest drop in body size is seen between LNIII-A and LNIII-B, and is confirmed by a significant Mann-Whitney result, with lengths experiencing a larger reduction in size than the widths (as confirmed by the effect size results) - reflecting the first indications of the change to a small robust body shape. Unfortunately the datasets from the west are too small to be able to trace this same pattern. In the second half of LNIII in both geographical areas, we can see the smallest cattle according to width measurements, although length measurements do not seem to get as small. From 3000 cal BC (LNIII-E) onwards, we start to see an increase in the importance of cattle according to \%NISP in the west, as seen in the previous plots. The lack of data from the east during the period 3000-2900 cal $\mathrm{BC}$, however, means that we cannot see the comparative pattern in this area, and there are no measurements from either region. During the following period, from 2900 to $2800 \mathrm{cal}$ BC (LNIII-F), however, there is an increase in size in both regions, as seen in the 200-year plot. The distribution of individual data points on the histograms (Fig. 13) highlights the differences between east and west during the second half of LNIII and during LNIV. The increase in size between LNIII$\mathrm{D}$ and $\mathrm{F}$ is very highly significantly different in the west according to the Mann-Whitney results (confirmed by a large 


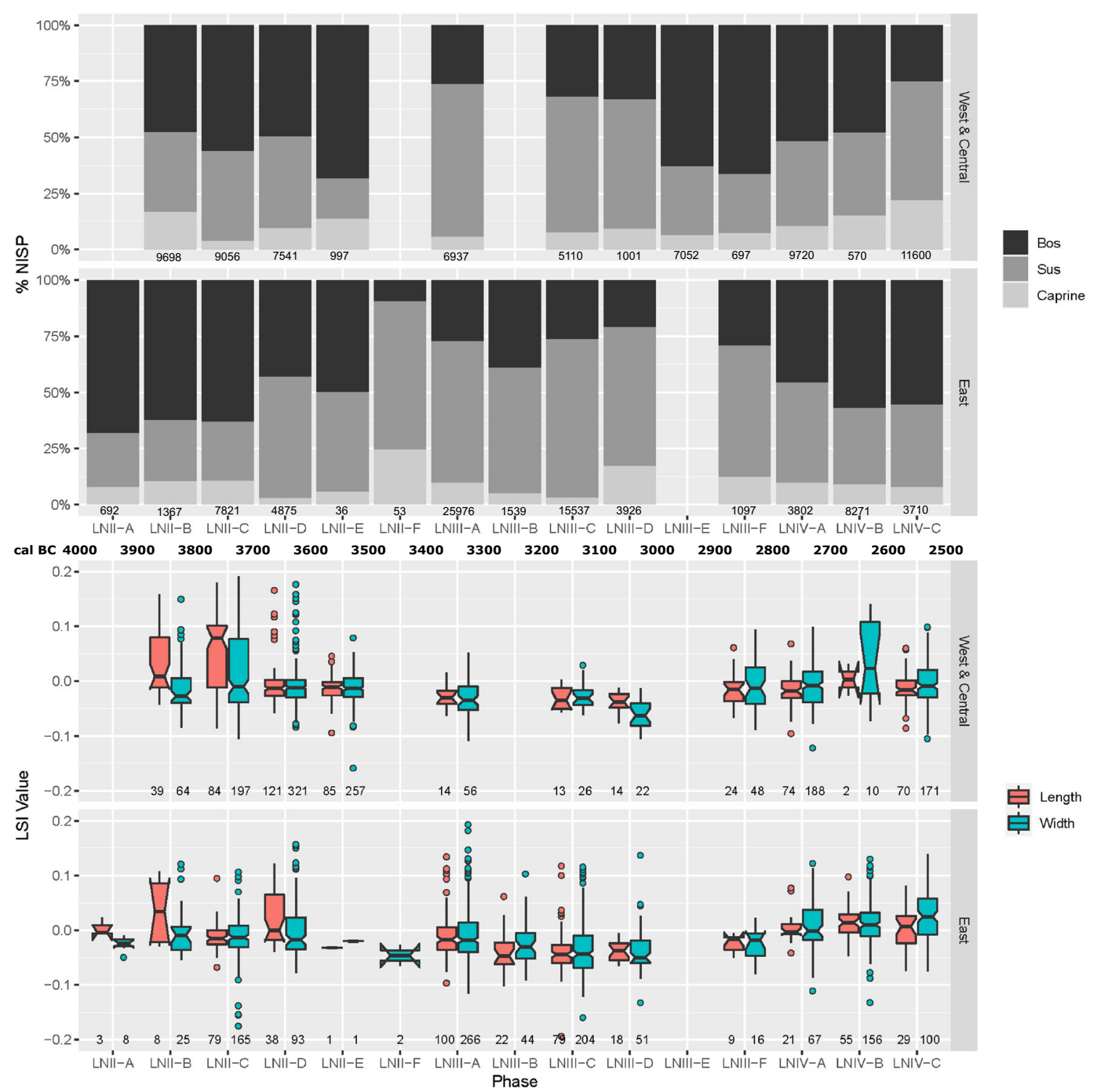

Fig. $12 \%$ NISP and log ratio box plots with 100 -year time slices

effect size result in the one sample of a reliable size), but the sample sizes from the east are too small for a reliable test. This evidence shows that cattle had already increased in size by the last 100 years attributed broadly to the Horgen period, although the high proportion of cattle in the preceding period shows that there is also the potential there for this change to have taken place even earlier. Both east and west show the presence of very small cattle during the period from 3200 to 3000 cal BC, but these small cattle disappear completely in the east by $\mathrm{c} 2500 \mathrm{cal} \mathrm{BC}$, but still persist in the west, albeit in relatively small numbers.

Using 100-year slices has provided more detail for the changes that took place at the transition between LNIII and LNIV (which could be attributed to the transition between the Horgen and Corded Ware cultures), where cattle seem to gain importance in the west earlier than in the east, with the peak in
$\%$ NISP between 3000 and 2800 cal BC in the west (LNIII-E and F), and between 2700 and 2500 cal BC (LNIV-B and C) in the east. There is also some correlation with this in the body size data, where medians on the box plots peak slightly earlier in the west (2800-2600 cal BC) compared to the east where the peak does not come until slightly later (c2700-2500 cal $\mathrm{BC}$ ). Quite a few large and moderate effect size results can be seen for the 100-year time slices. These highlight that the size change which takes place between LNIII-C and D and LNIV is truly significant particularly in the east of Switzerland but also in the west to a slightly smaller degree. Changes within the time attributed to the Corded Ware do not show significance according to the Mann-Whitney tests, or effect sizes, but there is high significance in the difference between the two regions in LNIV-A and C in both length and width measurements, and a moderate effect size for widths, indicating that 


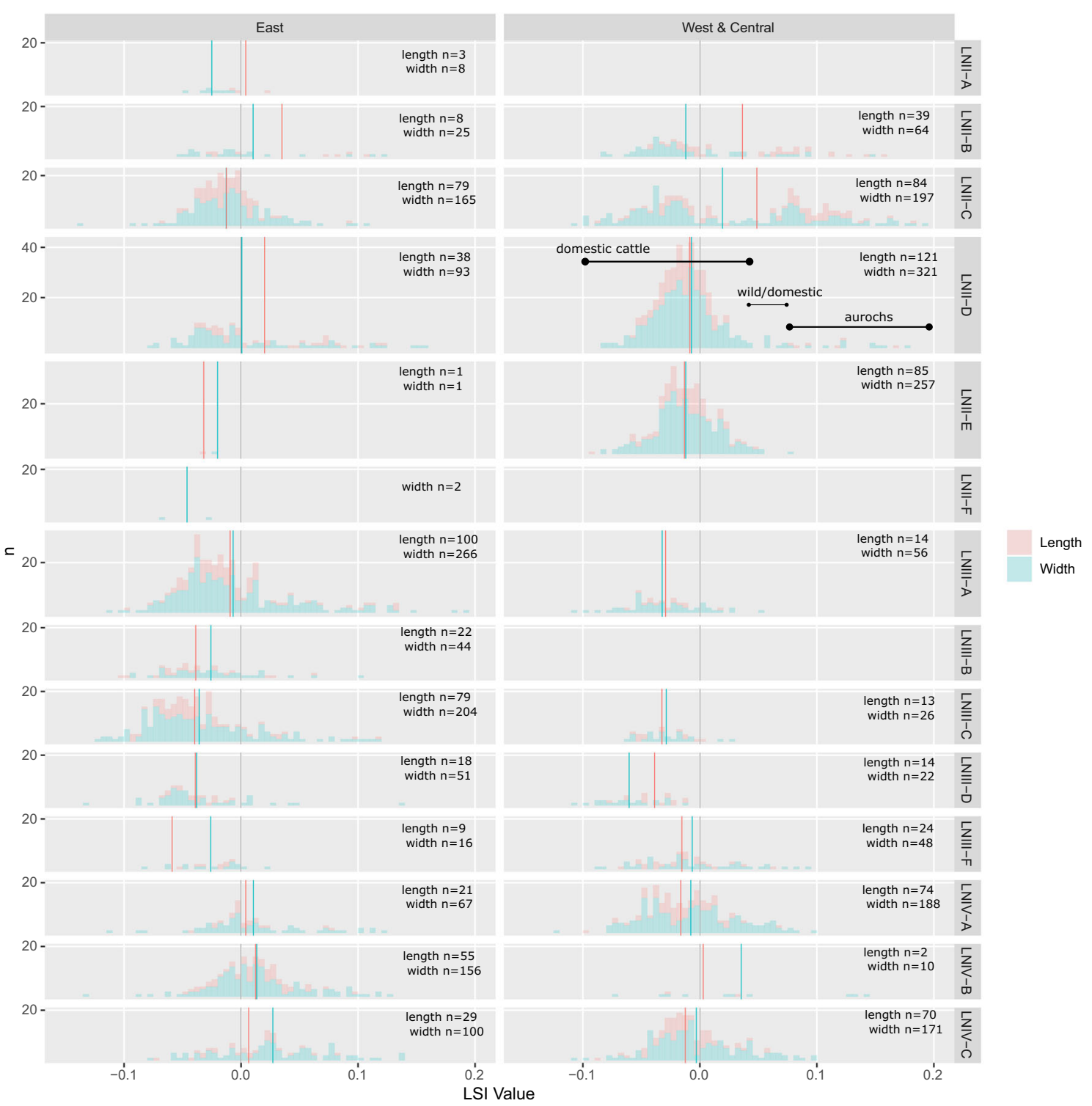

Fig. 13 Log ratio histogram with 100-year time slices. The standard is indicated with a black line, and length and width means indicated with red and green lines respectively.

there is truly a difference between the body size of cattle in these two areas.

\section{Discussion}

These results indicate that there was a clear correlation between cattle proportions (=importance?) and cattle body size in Neolithic Switzerland through much of the period from c4400 to $2500 \mathrm{cal} \mathrm{BC}$, in both eastern and western regions, with high proportions of cattle generally correlated with cattle with a larger body size.
They also show that the major changes in cattle prevalence and body size took place broadly in line with "cultural changes" in both areas as suggested by previous work undertaken in the Zurich region and French Jura (e.g. Hüster-Plogmann and Schibler 1997; Arbogast et al. 2006). However, this new work provides clearer detail in terms of the different mechanisms at play in each region, and the time scales across which these changes were taking place. The different scales used, as well as the fine temporal precision of the 100-year time slices, provide the opportunity to see in greater detail what was happening over time. 


\section{Exploitation of the aurochs during the Swiss Late Neolithic}

Clearly people were hunting aurochs in addition to keeping domestic cattle throughout the Swiss Late Neolithic, as indicated by the larger specimens appearing on the histograms. Aurochs are particularly prevalent during the period from 3900 to $3700 \mathrm{BC}$ in the western region. A high proportion of these remains are from one particular group of sites around the lake of Burgäschisee, as mentioned in the introduction - where a particularly high proportion of the faunal remains overall were from wild species (Boessneck et al. 1963; Stampfli 1964; Schäfer and Schibler, In Prep.). The prevalence of wild species during this period has previously been noted as part of an overall increase in hunting during short-term climatic fluctuations (Arbogast et al. 2006; Schibler 2006; Schibler et al. 1997a; Schibler and Jacomet 2010). The exact status of the aurochs during this period in terms of its more specific regionality needs to be explored in future work. After c3700 BC, aurochsen seems to appear in relatively small numbers in both the east and west and cannot have been formed a large part of the subsistence of the communities living across Switzerland.

\section{Cattle husbandry during the period from 4000-3400 cal BC}

This work has indicated that domestic cattle proportions and body size remained relatively stable throughout the period encompassing the Cortaillod and Pfyn cultures in both the east and west of Switzerland. Clearly aurochs were also being hunted during this period particularly during the period from 3900 to $3700 \mathrm{cal} \mathrm{BC}$, as noted above. There does not seem to be any clear difference between the pattern seen in the domestic cattle plots in eastern and western Switzerland, suggesting that similar methods of cattle exploitation and husbandry were taking place across both regions. Previous studies have shown that quite high proportions of cattle from Cortaillod and Pfyn layers at lake Zurich were killed at a relatively young age, indicating a focus on meat exploitation at this time, and potential for an increase in dairying towards the end of this period is also cited (Hüster-Plogmann and Schibler 1997).

\section{Cattle husbandry during the period from c3400-3000 cal BC}

During this time, which has been broadly attributed to the so called Horgen culture, an increase in pig production means that cattle remains make up much lower proportions of assemblages in both the east and west of Switzerland, although bone densities of cattle remains do not decrease (Schibler 2006), indicating that cattle herds were not necessarily smaller in size. Clearly cattle in both areas also become smaller in size, and in the east, we also see a bone shape change evident in a number of autopodial elements (Fig. 5, and Hüster-Plogmann and Schibler 1997), indicating that herds were made up of small robust cattle. Aurochs are still being hunted at this time, but in much smaller numbers than during earlier periods, and the overall decrease in size seen in the plots takes place despite their presence.

The small time slices used by this study have shown that the biggest shift in body size and shape took place between 3300 and $3200 \mathrm{cal} \mathrm{BC}$, but that body size continued to decrease until at least c3000 cal BC in both east and west Switzerland. There are a number of potential explanations for such a change in body size and shape. One option could be a deliberate selection by humans for cattle of small but robust statue for a particular economic purpose. Mortality information from some of the Zurich sites has suggested that cattle herds at this time (dominated by older individuals) were used primarily for traction, and pathological information from Arbon Bleiche 3, where a yoke was also recovered, has provided further evidence of this (Deschler-Erb and Marti-Grädel 2004; Leuzinger 2002). Although castrates are normally favoured for labour purposes (Hüster-Plogmann and Schibler 1997), whose bones are long and slender - completely the opposite of the cattle at this time - this does not rule out the use of smaller robust cattle for this purpose. Alternatively, this body size change could be related to the accidental impact of humans subjecting the animals to certain environmental conditions. Previous studies have argued that it could be related to a change in fodder type or living conditions, or that the small robust body shape may be the result of the cattle being used for traction at too young an age (Hüster-Plogmann and Schibler 1997), although it is not clear that the latter would stop them from growing to their normal size. A further hypothesis is that the reduction in body size could be the result of an insular approach to husbandry management, in which the cattle gene pool became very small due to a lack of new stock from outside. This should be considered in the light of the fact that pigs seemed to have a very high focus at this time. Even though cattle herds are still thought to have been a similar size (according to bone density data), it is still possible that pig husbandry may have formed a distraction that meant that cattle herds were not managed well or were managed in a very insular way.

Whatever the explanation, it is worth bearing in mind that during the Neolithic period, a general reduction in size has been cited in many European areas, so this pattern is not particularly surprising (Boessneck et al. 1971; Bökönyi 1974; Boessneck and von den Driesch 1978; Lasota-Moskalewska 1980; Manning et al. 2015; Tresset 2000; Vigne 1988).

\section{Cattle husbandry between 3000 and 2700 cal BC (the Horgen-Corded Ware/Auvernier Cordé transition)}

This study has shown changes in cattle \%NISP and body size between 3000 and $2700 \mathrm{cal} \mathrm{BC}$ in the different regions of 
Switzerland in much greater focus than previously possible. It is clear that during this time in both areas, domestic cattle became both more important compared to other domestic species and also larger in size. Aurochs do seem to continue to have been hunted, but in very small numbers until around $2800 \mathrm{BC}$, when in the east they become very slightly more prevalent. The changes in domestic cattle were taking place at a different pace in the east and west. Western areas see an earlier rise in both cattle proportions and an earlier peak in body size, although eventually cattle become largest in the east. This is particularly interesting when one considers the previously suggested hypothesis that the increase in the importance of cattle at this time could be related to an incoming new cattle population linked with the introduction of the Corded Ware culture (Arbogast et al. 2006). This interpretation fits with the narrative of human migration which has been suggested by recent genetic work (Allentoft et al. 2015; Haak et al. 2015; Olalde et al. 2018). However, with this explanation, one would expect the first evidence to be coming from the east rather than the west, from the direction in which the Corded Ware influence was travelling. One large frustration in this study is the gap in data for the period between 3000 and $2900 \mathrm{cal}$ BC. However, the pattern at Chalain in the French Jura just outside of the study area for this analysis to the west (Arbogast et al. 2006) indicates that, certainly in the west, an increase in body size had already taken place by $2980 \mathrm{cal} \mathrm{BC}$, earlier than the arrival of Corded Ware in eastern Switzerland at around $2750 \mathrm{cal} \mathrm{BC} \mathrm{(Hafner} \mathrm{and} \mathrm{Suter} \mathrm{2003).}$

With this in mind, it is worth considering whether the change in cattle husbandry seen in western Switzerland is the result of other influences. This would not be entirely surprising, as evidence from material culture in the region has shown long-standing links to regions in the west. In fact between 3000 and $2700 \mathrm{cal} \mathrm{BC}$, many sites in western Switzerland are attributed to the so called Lüscherz Culture, which is thought to have links to the Paris Basin and the Poitou and Languedoc regions of France (see, for example. Affolter and Suter 2017, Fig. 4). There is also evidence that this region had links with people to the north, as pottery in the style of the so called Wartberg Group of western Germany has also been recovered here (Gross 1991). This pottery is particularly relevant because its deposition context has been dated to 2853$2843 \mathrm{cal} \mathrm{BC}$, earlier than the perceived arrival of the Corded Ware culture. It may be, therefore, that the larger cattle in the west had different origins to those in the east.

Clearly the mechanisms around the changes in cattle husbandry at this time need to be further explored, integrating data across a wider area of Central and Western Europe.

\section{Potential evidence for early cattle "improvement"}

A high correlation is seen between the proportions of cattle remains and their body size at all levels of temporal precision in both the east and west; cattle decrease in both proportion and size between approximately 3400 and $3000 \mathrm{cal} \mathrm{BC}$ but then increase in both proportion and size (and also find density, where data are available-Schibler 2006) going into the period of the Corded Ware and Auvernier Cordé Cultures. This increase in size is particularly interesting, as it seems to go against the pattern seen across Neolithic Europe where size tends to get smaller throughout time (e.g. Manning et al. 2015).

The timing of this increase in size, broadly in line with the introduction of Corded Ware culture, seems too coincidental to be ignored; although as mentioned above, the results of this study have shown that larger cattle could have come from either the east or the west or perhaps even both. However, other factors do also need to be ruled out.

An alternative explanation for an increase in the size of cattle could be that aurochs were being hunted more intensively at this time. However, none of the cattle from this period is reaching the sizes seen in the earlier Cortaillod, where aurochs are common (Fig. 9), and the size increase is also seen at the lower end of the range (e.g. in domestic females), particularly in the sample from the east, so this explanation can be ruled out.

If the majority of these cattle are domestic, then an alternative explanation could be that the proportion of males in cattle herds increased after $3000 \mathrm{cal} \mathrm{BC}$. However, as there is no indication of this in the metacarpal pattern, and additionally the smallest individuals, likely females, also seem to be increasing in size, this also seems unlikely. It is also worth bearing in mind the possible impact of castration, which would have had an impact on bone length. However, the metapodial plots above do not indicate that castrates were dominating assemblages at this time, and width measurements also increase at a similar rate, so this cannot be a major explanation.

The pattern therefore suggests that at the time when cattle may have become most important (\%NISP was increasing, as well as cattle bone densities-see e.g. Schibler et al. 1997a, 1997b; Schibler 2006), some effort was also being put into maintaining or even "improving" the body size and health of the herds. This is most likely to have been through introduction of new larger stock, as there is little evidence that many larger cattle were maintained through the Horgen period.

In all areas of Switzerland, the larger cattle are being recovered from the same settlement sites which also yielded the smaller cattle in the earlier Horgen layers, and in the east, it is particularly clear in the histograms (Fig. 10) that by the end of the Corded Ware period, the small-sized cattle had pretty much disappeared from sites in the region, so it is unlikely that these two populations were co-existing separately from each other. Additionally, this is a process that is clearly taking place over time and is not a sudden replacement of one population with another. All of these aspects suggest that there 
was a deliberate human choice to incorporate the larger cattle into herds, and they were preferred over the smaller stock.

The process described above is logical if human choice is considered to have been the main driving force behind cattle body size change in the past, but there are questions around whether these kinds of choices were being made as early as the Neolithic period in Europe. In general the expansion of Roman influence a number of millenia later is often cited as the earliest evidence for deliberate "improvement" of livestock across much of Europe (e.g. Albarella et al. 2008; Groot 2017; Groot and Deschler-Erb 2015; Lauwerier 1988; Lepetz 1996; Pigiere 2017; Teichert 1984; Valenzuela-Lamas and Albarella 2017). Recent work, however, has indicated that in Italy at least, some changes in cattle and sheep body size attributed to potential "improvement" existed earlier, in the late Bronze Age (Trentacoste et al. 2018). In the PostRoman period, there are plenty of examples of deliberate livestock improvement in various different European areas, such as Medieval (Albarella 1997) and Early Modern England (Grau-Sologestoa and Albarella 2019), as well as Iberia during the Islamic period (Davis 2008), to name just a few.

To the author's knowledge, there are no other examples of this kind of increase in cattle body size correlated with a clear increase in cattle proportions and find densities in Neolithic Europe, and this may therefore constitute some of the earliest evidence for this kind of deliberate management choice in the European archaeological record. The situation is further enhanced by the possibility that this process could have been taking place in both the east and west of Switzerland, through stock introduced from different places. Further investigation is now needed on cattle assemblages from this period, from both inside and outside of the geographical range linked to Corded Ware, in order to see if there is any evidence for this kind of pattern elsewhere, and if this phenomenon can be more clearly linked to the influence of this Corded Ware in the east, and/or to other influences in the west.

\section{Benefits of analysing data at different temporal scales}

Finally, it is also important to assess the technical side of this study, in terms of how useful the analysis of this dataset at these different scales of precision has been. Certainly this work has provided far more detail to our knowledge of changes in cattle husbandry through time, and it has also allowed for the patterns to be verified using both larger and smaller sample sizes at different levels of precision. The inclusion of the 300year groups has also been very useful, because it groups the data in a slightly different way to the 200- and 100-year groups, whilst also confirming the same patterns. If datasets allow for the splitting of data in this way, it seems like a very useful exercise for analysis in future.

\section{Conclusion}

This analysis has shown how using different scales of temporal precision can help with identifying patterns in prehistoric cattle husbandry through time. In the case of Neolithic Switzerland, it has shown that changes in \%NISP and body size are well-correlated across a long time scale and that changes were broadly concurrent with broad cultural changes indicated by material culture in both the east and west of Switzerland. However, the use of narrow time slices has allowed a closer look at the complexity of these changes and in particular has highlighted regional differences in timing in the adoption of a more cattle-focused economy sometime between 3000 and $2800 \mathrm{cal} \mathrm{BC}$. An increase in the proportion and body size of cattle around this time is thought to be due to the introduction of new large cattle into the area, but it seems that this process started in western Switzerland prior to $2800 \mathrm{cal} \mathrm{BC}$, throwing into doubt the idea that this pattern in all areas of Switzerland is a direct result of the introduction of the Corded Ware culture. It is therefore possible that cattle may have also been brought from areas to the west or north.

The body size pattern is the opposite of what has been seen in other Central European areas, where a decrease in size is seen throughout the Neolithic period, and may constitute some of the earliest evidence for the deliberate "improvement" of cattle on the continent. Future work must focus on this specific time period across a wider European area, in order to see if any evidence of this pattern can be seen elsewhere, and if this new cattle-focused economy can be clearly linked to the arrival of Corded Ware material culture and burial practices.

Supplementary Information The online version contains supplementary material available at https://doi.org/10.1007/s12520-020-01252-6.

Acknowledgements Special thanks go to Jörg Schibler for his invaluable advice and our many interesting chats on Swiss Neolithic cattle, and to the rest of the zooarchaeology team at IPAS for providing data and answering my many questions. Thanks also to Ferran Antolin and Georgina Prats for their help with the site coordinates, and to Silvia Valenzuela-Lamas and Angela Trentacoste for their help with R. Thank you to the zooarchaeology team at the University of Sheffield for a very useful discussion around body size changes and statistics, and to Eda Gross for a useful discussion on Swiss Neolithic cultures. Finally, thanks to Ulrich Eberli at the Museum für Urgeschichte in Zug and Christian Harb, Stephanie Chamberlain and staff at the Kantonsarchäologie Zurich for providing access to the material from Zug Sennweid and Zurich Versicherung. This research was funded through a European Commission Marie Sklodowska-Curie European Fellowship (Grant no. 792076).

Funding Open Access funding provided by University of Basel. This research was funded through a European Commission Marie Skłodowska-Curie European Fellowship (Proposal 792076-LAKEBOS).

Availability of data and material The database is due to be published later this year in an OpenAccess repository (https://doi.org/10.6078/ M7H13049). 


\section{Compliance with ethical standards}

Conflict of interest The author declares that she has no conflict of interest.

Code availability The R packages used have been cited within the text.

Open Access This article is licensed under a Creative Commons Attribution 4.0 International License, which permits use, sharing, adaptation, distribution and reproduction in any medium or format, as long as you give appropriate credit to the original author(s) and the source, provide a link to the Creative Commons licence, and indicate if changes were made. The images or other third party material in this article are included in the article's Creative Commons licence, unless indicated otherwise in a credit line to the material. If material is not included in the article's Creative Commons licence and your intended use is not permitted by statutory regulation or exceeds the permitted use, you will need to obtain permission directly from the copyright holder. To view a copy of this licence, visit http://creativecommons.org/licenses/by/4.0/.

\section{References}

Affolter J, Suter PJ (2017) Silexartefakte: Rohstoffe - Werkzeuge und (Jagd-)Waffen. In: Suter PJ (ed) Um 2700 v. Chr.- Wandel Und Kontinuität in Den Ufersiedlungen Am Bielersee, Archäologischer Dienst Des Kantons Bern, pp. 290-309

Albarella U (1997) Shape variation in cattle metapodials: age, sex or breed? Some examples from Medieval and post-medieval sites. Anthropozoologica 25-26:37-47

Albarella U, Johnstone C, Vickers K (2008) The development of animal husbandry from the Late Iron Age to the end of the Roman period: a case study from South-East Britain. J Archaeol Sci 35:1828-1848. https://doi.org/10.1016/j.jas.2007.11.016

Allentoft ME, Sikora M, Sjögren K-G, Rasmussen S, Rasmussen M, Stenderup J, Damgaard PB, Schroeder H, Ahlström T, Vinner L, Malaspinas A-S, Margaryan A, Higham T, Chivall D, Lynnerup N, Harvig L, Baron J, Casa PD, Dąbrowski P, Duffy PR, Ebel AV, Epimakhov A, Frei K, Furmanek M, Gralak T, Gromov A, Gronkiewicz S, Grupe G, Hajdu T, Jarysz R, Khartanovich V, Khokhlov A, Kiss V, Koláŕ J, Kriiska A, Lasak I, Longhi C, McGlynn G, Merkevicius A, Merkyte I, Metspalu M, Mkrtchyan R, Moiseyev V, Paja L, Pálfi G, Pokutta D, Pospieszny Ł, Price TD, Saag L, Sablin M, Shishlina N, Smrčka V, Soenov VI, Szeverényi V, Tóth G, Trifanova SV, Varul L, Vicze M, Yepiskoposyan L, Zhitenev V, Orlando L, Sicheritz-Pontén T, Brunak S, Nielsen R, Kristiansen K, Willerslev E (2015) Population genomics of Bronze Age Eurasia. Nature 522:167-172. https://doi.org/10.1038/ nature 14507

Arbogast R-M, Jacomet S, Magny M, Schibler J (2006) The significance of climate fluctuations for lake level changes and shifts in subsistence economy during the late Neolithic (4300-2400 b.c.) in central Europe. Veg. Hist. Archaeobotany 15:403-418. https://doi.org/10. 1007/s00334-006-0053-y

Auguie B, (2017). gridExtra: Miscellaneous Functions for "Grid" Graphics. R package version 2.3. https://CRAN.R-project.org/ package $=$ gridExtra

Becker C, Johansson F, (1981). Die Tierknochenfunde. Zweiter Bericht., Die neolithischen Ufersiedlungen von Twann. Vol 11. Haupt Verlag, Bern.

Boessneck J, von den Driesch A, (1978). Die Tierknochenfunde aus der Neolithischen Siedlung auf dem Fikirtepe bei Madiky am Marmarameer. Institut für Palaeoanatomie,
Domestikationsforschung und Geschichte der Tiermedizin der Universität München, München.

Boessneck J, Jéquier J-P, Stampfli HR (1963) Seeberg Burgäschisee-Süd, Teil 3: Die Tierreste, Acta Bernensia II. Stämpfli Verlag, Bern

Boessneck J, von den Driesch A, Meyer-Lemppenau, U., Wechsler von Ohlen E, (1971). Die Tierknochenfunde aud dem Oppidum von Manching. Wiesb. Ausgrabungen Manching 6.

Bökönyi S (1974) History of Domestic Animals in Central and Eastern Europe. Akadémiai Kiadó, Budapest

Bopp-Ito M (2018) Archaeozoological study on the Bronze Age Alpine settlement Savognin-Padnal in the Canton of Grisons. In: Switzerland ( $\mathrm{PhD}$ Thesis). University of Basel, Basel

Borello MA, Chaix L (1983) Étude de la faune de HauteriveChampréveyres (Neuchâtel): Bronze final (1979-1980). Extr Bull Société Neuchâtel Sci Nat 106:159-169

Braschler S (2010) Die Fundstellen Untervaz-Haselboden und Haselbodensenke. Bündner Monatsblatt: Zeitschrift für Bündner Geschichte, Landeskunde und Baukultur 4:369-387

Braschler S, Schibler J (2009) Archäozoologische Auswertung der neolithischen Tierknochen aus der Fundstelle Mumpf AG-Kapf. Jahrb Archäol Schweiz 92:38-42

Breuer G, Rehazek A, Stopp B (1999) Grössenveränderungen des Hausrindes. Osteometrische Untersuchungen grosser Fundserien aus der Nordschweiz von der Spätlatènezeit bis ins Frümittelalter am Beispiel von Basel, Augst (Augusta Raurica) und SchleitheimBrüel. Jahresber. Aus August Kaiseraugst 20:207-228

Chaix L (1976a) La faune de la fouille Yverdon-Garage Martin. In: Kaenel G (ed) La Fouille Du "Garage Martin-1973". Cahiers d'Archéologie Romande. Musée d'archéologie et d'histoire, Lausanne, pp 181-228

Chaix L (1976b) La faune du dolmen MXI à Sion (Valais, Suisse). Problèmes d'interprétation. In: Millotte JP, Thévenin A, Chertier B (eds) Actes Du 9e Congress de l'Union International Des Sciences Préhistoriques et Protohistoriques, Themes Specialises. CNRS, Nice, pp 56-74

Chaix L, (1976c). La faune néolithique du Valais (Suisse). Ses caractères et ses relations avec les faunes néolithiques des régions proches. Unpubl. PhD Thesis, University of Geneva, Genève.

Chaix L (1977) La faune de la station de Pont-de-Thielle (néolithique récent). Arch Sci 30:433-464

Chaix L (1984) Les restes de vertébrés du site de Bavois-en-Raillon (Vaud, Suisse) (Bronze final. Cah). D’Archéologie Romande 28: $67-80$

Chaix L, (1986). La Faune, in: Borrello MA, Brochier JL, Chaix L, Hadorn P (Eds.), Cortaillod-Est, Un Village Du Bronze Final: Nature et Environment. pp. 47-73.

Chaix L (1989) La faune du site de Schützenmatt. Jahrb Schweiz Ges Für Ur- Frühgesch 72:43-48

Chaix L (1990a) La faune d'Ayent-le-Château (Valais). Suisse; Bronze ancien et Bronze final Jahrb Schweiz Ges Für Ur- Frühgesch 73:44 46

Chaix L (1990b) La faune de Vex-le-Château (Valais). Suisse; du Néolithique moyen au Bronze final Jahrb Schweiz Ges Für UrFrühgesch 73:47-50

Chaix L, Guintard B, Olive C,(1991). Aspects de la transition entre les populations de chasseurs et d'éleveurs dans les Alpes du Nord et le sud du Jura: les données de l'archéozoologie, in: Mésolithique et Néolithisation En France et Dans Les Régions Limitrophes. C.T.H.S, pp. 309-322.

Chaix L, Olive C, Ramseyer D, Studer J (1983) La faune des secteurs 33 et 38 de la station néolithique Portalban/Les Grèves (civilisation de Horgen). Bulletin Société Fribourgoise Sciences Naturelles 72:44 55

Chiquet P, (2012). La faune du Néolithique moyen: analyse des modes d'exploitation des ressources animales et contribution à 
l'interprétation de l'espace villageois“, in La station lacustre de Concise 4. Cah. D’Archéologie Romande 131.

Clason AT, (1991). Viehzucht, Jagd und Knochenindustrie der Pfyner Kultur, in: Waterbolk, H.T., Zeist, W. (Eds.), Niederwil. Eine Siedlung der Pfyner Kultur. Bd. III: Naturwissenschaftliche Untersuchungen. Academia Helvetica 1 III. Verlag Paul Haupt, Bern and Suttgart, pp. 115-220.

Clutton-Brock J (1990) Animal remains from the Neolithic Lake Village Site of Yvonand IV, Canton de Vaud, Switzerland. Arch Sci 43:197

Davis SJM (1996) Measurements of a group of adult female shetland sheep skeletons from a single flock: A baseline for zooarchaeologists. J Archaeol Sci 23:593-612. https://doi.org/10. 1006/jasc. 1996.0056

Davis SJM (2008) Zooarchaeological evidence for Moslem and Christian improvements of sheep and cattle in Portugal. J Archaeol Sci 35: 991-1010. https://doi.org/10.1016/j.jas.2007.07.001

Degerbøl M, Fredskild B (1970) The Urus (Bos Primigenius Bojanus) and Neolithic Domesticated Cattle (Bos Taurus Domesticus Linne) in Denmark. The Royal Danish Academy of Science and Letters, Copenhagen

Deschler-Erb S ( 2005). Archäozoologie, in: P.J., S., Ramstein, M. (Eds.), Fundberichte und Aufsätze / Chronique archéologique et textes. Archäologie im Kanton Bern. pp. 108-109.

Deschler-Erb S, Marti-Grädel E, (2004). Viehhaltung und Jagd. Ergebnisse der Untersuchung der handaufgelesenen Tierknochen, in: Jacomet S, Leuzinger U, Schibler J (Eds.), Die Jungsteinzeitliche Seeufersiedlung Arbon Bleiche 3. Umwelt Und Wirtschaft., Archäologie Im Thurgau.

Desse J, (1976). La faune du site archéologique Auvernier-Brise Lames, canton de Neuchâtel (Suisse. Thèse Poitiers.

Doppler T, Gerling C, Heyd V, Knipper C, Kuhn T, Lehmann MF, Pike AWG, Schibler J (2017) Landscape opening and herding strategies: Carbon isotope analyses of herbivore bone collagen from the Neolithic and Bronze Age lakeshore site of Zurich-Mozartstrasse, Switzerland. Quat Int 436:18-28. https://doi.org/10.1016/j.quaint. 2015.09.007

Ebersbach R (2002) Archäozoologie. In: Achour-Uster C, Eberli U, Ebersbach R, Favre P (eds) Die Seeufersiedlungen in Horgen. Die neolithischen und bronzezeitlichen Fundstellen Dampfschiffsteg und Scheller. Monografien der Kantonsarchäologie Zürich. Fotorotar, Zürich, pp 181-203

Ebersbach, R., (2005). Die Tierknochen aus den Epi-Rössener Schichten, in: Rigert, E., Ebneter, I., Ebersbach, R., Akeret, Ö., Leuzinger, U. (Eds.), Die Epi-Rössener Siedlung von Sevelen SG-Pfäfersbüel. Jahrbuch der Schweizerischen Gesellschaft für Ur- und Frühgeschichte. pp. $41-86$.

Ebersbach R, Hüster-Plogmann H, Stopp B, Schibler J (2010) Archäozoologie. In: Eberli U (ed) Die horgenzeitliche Siedlung Pfäffikon-Burg. Monographien der Kantonsarchäologie Zürich. Fotorotar, Zürich, pp 262-299

Ginella F, Schibler J (2020) Grosstierknochen. In: Heitz C (ed) Abseits Der Grossen Seen: Archäologie Und Erhaltung Der Neolithischen Unesco-Welterbe-Fundstelle Seedorf. Lobsigesee, Hefte Zur Archäologie Im Kanton Bern, pp 208-256

Glass M, Schibler J, (2000). Archäozoologsiche Auswertung der Tierknochen", in: Hafner, A., Suter, P.J. (Eds.), am Bielersee aufgrund der Rettungsgrabungen von Nidau und Sutz-Lattrigen. Ufersiedlungen am Bielersee. Berner Lehrmittel- und Medienverlag, Band, p. 3400

Grau-Sologestoa I, Albarella U (2019) The 'long' sixteenth century: a key period of animal husbandry change in England. Archaeol Anthropol Sci 11:2781-2803. https://doi.org/10.1007/s12520-018-0723-6
Groot M (2017) Developments in animal husbandry and food supply in Roman Germania Inferior. Eur J Archaeol 20:451-471

Groot M, Deschler-Erb S (2015) Market strategies in the Roman provinces: different animal husbandry systems explored by a comparative regional approach. J Archaeol Sci Rep 4:447-460

Gross E (1991) Die Sammlung Hans Iseli in Lüscherz, Ufersiedlungen am Bielersee. Staatlicher Lehrmittelverlag, Bern

Gross E (2017) Cultural and chronological attribution of pottery on the move: From rigid time-space schemata towards flexible microarchaeological 'messworks,'. In: Heitz C, Stapfer R (eds) Mobility and Pottery Production: Archaeological and Anthropological Perspectives. Sidestone Press, Leiden, pp 169-186

Gutzwiller P, Marti R, Schibler JSJ, Veszeli M, (1996). Zufluchtsort in unsicherer Zeit, in: Die Portifluh als markanter Zeuge früher Besiedlung. Heimatbuch, Nunningen“. Verlag Jeger-Moll, Breitenbach, pp. 75-84.

Haak W, Lazaridis I, Patterson N, Rohland N, Mallick S, Llamas B, Brandt G, Nordenfelt S, Harney E, Stewardson K, Fu Q, Mittnik A, Bánffy E, Economou C, Francken M, Friederich S, Pena RG, Hallgren F, Khartanovich V, Khokhlov A, Kunst M, Kuznetsov P, Meller H, Mochalov O, Moiseyev V, Nicklisch N, Pichler SL, Risch R, Rojo Guerra MA, Roth C, Szécsényi-Nagy A, Wahl J, Meyer M, Krause J, Brown D, Anthony D, Cooper A, Alt KW, Reich D (2015) Massive migration from the steppe was a source for Indo-European languages in Europe. Nature 522:207-211. https://doi.org/10.1038/ nature 14317

Hafner A, Suter PJ, (2003). Das neolithikum in der Schweiz. J Neolithic Archaeol. 5. https://doi.org/10.12766/jna.2003.4

Hartmann-Frick H (1959) Die Tierwelt des prähistorischen Siedlungsplatzes auf dem Eschner Lutzengüetle Fürstentum Liechtenstein (Neolithikum bis La Tène). Jahrb Hist Ver Für Fürst Liecht 59:5-224

Hartmann-Frick H (1965) Die Fauna der befestigen Höhensiedlung auf dem Borscht Fürstentum Liechtenstein (Neolithikum bis Latène). Wallisellen-Zürich, Vaduz

Hescheler K, Rüegger J (1940) Die Wirbeltierreste aus den Pfahlbauten des Baldeggersees nach den Grabungen von 1938 und 1939. Vierteljahrsschr Naturforschenden Ges Zür 85:59-70

Higham CFW (1968a) Size trends in prehistoric European domestic fauna, and the problem of local domestication. Acta Zool Fenn 120:121

Higham CFW (1968b) Patterns of rehistoric economic exploitation on the alpine foreland. Vierteljahrsschrift der Naturforschenden Geschellschaft in Zürich 113(1):41-92

Huber R, Schaeren G, (2009). Zum Stand der Pfahlbauforschung im Kanton Zug. Tugium Jahrb. Staatsarch. Kantons Zug Amtes Für Denkmalpfl. Archäol. Kanton. Mus. Für Urgesch. Zug Burg Zug 25.Hüster-Plogmann, H., Schibler, J., 1997. Archäozoologie, in: Schibler, J., Hüster-Plogmann, H., Jacomet, S., Brombacher, C., Gross-Klee, E., Rast-Eicher, A. (Eds.), Ökonomie Und Ökologie Neolithischer Und Bronzezeitlicher Ufersiedlungen Am Zürichsee, Monographien Der Kontonsärchäologie Zürich. Zürich and Egg, Fotorotar, pp. 40-121.

Hüster-Plogmann H, Schibler J, Jacomet S (1999a) The significance of aurochs as a hunted animal in the Swiss Neolithic. In: Weniger G-C (ed) Archäologie und Biologie des Aurochsen. Neanderthal Museum, Mettman, pp 151-160

Hüster-Plogmann H, Schibler J, Steppan K, (1999b). The relationship between wild mammal exploitation, climatic fluctuations, and economic adaptations. A transdisciplinary study on Neolithic sites from the lake Zurich region, Southwest Germany and Bavaria. In: Becker C (Ed.), Historia Animalium Ex Ossibus. Festschrift Für Angela von Den Driesch. Verlag Marie Leidorf GmbH, Rahden. 
Jacomet S (2007) Neolithic plant economies in the northern Alpine Foreland from 5500-3500 cal BC. In: Colledge S, Conolly J (eds) The origins and spread of domestic plants in southwest Asia and Europe. Left Coast Press, Walnut Creek, pp 221-258

Johnstone CJ (1999) Looking a gift horse in the mouth: the problems of using archived and published biometrical data. In: Anderson S (ed) Current and recent research in osteoarchaeology 2. Oxbow Books, Oxford pp. 48-50

Kaufmann B (1983) Die Skelettreste von Scuol-Munt, Baselgia. Antiqua 9:164-179

Kuhn E (1935) Die Fauna des Pfahlbaues Obermeilen am Zürichsee. Vierteljahrsschr Naturforschenden Ges Zür 80:65-154

Kuhn E (1937) Die Fauna der Wallsiedlung im Borscht (EndneolithikumLa Tène). Jahrb Hist Ver Für Fürst Liecht 37:4-42

Kuhn E, Güller A, (1946). Die Tierreste des bronzezeitlichen Pfahlbaues in der Bleiche von Arbon (Kt. Thurgau. Eclogae Geol. Helvetiae 39, Basel, 364-366, 946.

Lasota-Moskalewska A (1980) Morphotic changes of domestic cattle skeleton from the Neolithic age to the beginning of the Iron Age. Wiadomści Archeol 45:119-167

Lauwerier R, (1988). Animals in Roman times in the Dutch eastern river area. Nederlandse Oudheden 12. Project Oostelijk Rivierengebied 1, Amersfoort.

Lepetz S,( 1996). Effets de la romanisation sur l'e'levage et la diète carnée dans les établissements ruraux du nord de la Gaule. L'exemple de l'augmentation de la stature des animaux domestiques, in: Bayard D, Collart J-L (Eds.), De La Ferme Indigène à La Villa Gallo-Romaine. Amiens: Socie' Té de Pré Histoire Du Nord et de La Picardie, (Revue Archéologique de Picardie; Numéro Spé Cial 11). pp. 317-324.

Leuzinger U, (2002). Holzartefakte, in: De Capitani A, Deschler-Erb S., Marti-Grädel E, Schibler J (Eds.), Die Jungsteinzeitliche Seeufersiedlung Arbon-Bleiche 3: Funde, Archäologie Im Thurgau. pp. 76-114.

Leuzinger U, (2007). Pfyn Breitenloo - die jungsteinzeitliche Pfahlbausiedlung. Archäol. Im Thurgau 14.

Manning K, Timpson A, Shennan S, Crema E (2015) Size Reduction in Early European Domestic Cattle Relates to Intensification of Neolithic Herding Strategies. PLoS One 10:e0141873. https://doi. org/10.1371/journal.pone.0141873

Marti-Grädel E, (2017). Archäozoologische Untersuchungen zu Viehhaltung, Jagd und Fischfang, in: Suter PJ (Ed.), Um 2700 v. Chr.- Wandel Und Kontinuität in Den Ufersiedlungen Am Bielersee, Archäologischer Dienst Des Kantons Bern. pp. 160-193.

Meadow R (1999) The use of size index scaling techniques for research on archaeological collections from the Middle East. In: Becker C, Manhart H, Peters J, Schribler J (eds) Historia Animalium Ex Ossibus: Festschrift Fur Angela von Den Driesch. Verlag Marie Leidorf GmbH, Rahden/Westf

Morel P (2000) La faune: détermination ostéologique. Archéologie fribourgeoise 15

Olalde I, Brace S, Allentoft ME, Armit I, Kristiansen K, Booth T, Rohland N, Mallick S, Szécsényi-Nagy A, Mittnik A, Altena E, Lipson M, Lazaridis I, Harper TK, Patterson N, Broomandkhoshbacht N, Diekmann Y, Faltyskova Z, Fernandes D, Ferry M, Harney E, de Knijff P, Michel M, Oppenheimer J, Stewardson K, Barclay A, Alt KW, Liesau C, Ríos P, Blasco C, Miguel JV, García RM, Fernández AA, Bánffy E, Bernabò-Brea M, Billoin D, Bonsall C, Bonsall L, Allen T, Büster L, Carver S, Navarro LC, Craig OE, Cook GT, Cunliffe B, Denaire A, Dinwiddy KE, Dodwell N, Ernée M, Evans C, Kuchařík M, Farré JF, Fowler C, Gazenbeek M, Pena RG, Haber-Uriarte M, Haduch E, Hey G, Jowett N, Knowles T, Massy K, Pfrengle S, Lefranc P, Lemercier O,
Lefebvre A, Martínez CH, Olmo VG, Ramírez AB, Maurandi JL, Majó T, McKinley JI, McSweeney K, Mende BG, Modi A, Kulcsár G, Kiss V, Czene A, Patay R, Endrődi A, Köhler K, Hajdu T, Szeniczey T, Dani J, Bernert Z, Hoole M, Cheronet O, Keating D, Velemínský P, Dobeš M, Candilio F, Brown F, Fernández RF, Herrero-Corral A-M, Tusa S, Carnieri E, Lentini L, Valenti A, Zanini A, Waddington C, Delibes G, Guerra-Doce E, Neil B, Brittain M, Luke M, Mortimer R, Desideri J, Besse M, Brücken G, Furmanek M, Hałuszko A, Mackiewicz M, Rapiński A, Leach S, Soriano I, Lillios KT, Cardoso JL, Pearson MP, Włodarczak P, Price TD, Prieto P, Rey P-J, Risch R, Rojo Guerra MA, Schmitt A, Serralongue J, Silva AM, Smrčka V, Vergnaud L, Zilhão J, Caramelli D, Higham T, Thomas MG, Kennett DJ, Fokkens H, Heyd V, Sheridan A, Sjögren K-G, Stockhammer PW, Krause J, Pinhasi R, Haak W, Barnes I, Lalueza-Fox C, Reich D (2018) The Beaker phenomenon and the genomic transformation of northwest Europe. Nature 555:190-196. https://doi.org/10.1038/nature25738

Pigiere F (2017) The evolution of cattle husbandry practices in the Roman period in Gallia Belgica and western Germania Inferior. Eur J Archaeol 20:472-493

Plüss P, (2011). Die bronzezeitliche Siedlung Cresta bei Cazis (GR): Die Tierknochen. Collect Archæologica 9.

Popkin PRW, Baker P, Worley F, Payne S, Hammon A (2012) The Sheep Project (1): determining skeletal growth, timing of epiphyseal fusion and morphometric variation in unimproved Shetland sheep of known age, sex, castration status and nutrition. J Archaeol Sci 39: 1775-1792. https://doi.org/10.1016/j.jas.2012.01.018

Primas M (1985) Cazis-Petrushügel in Graubünden, in: Neolithikum, Bronzezeit, Spätmittelalter. In: Zürcher Studien zur Archäologie 4. Zürich, Juris

R Core Team (2020) R: A language and environment for statistical computing. In: R Foundation for Statistical Computing, Vienna URL https://www.R-project.org/

Rageth J, (1998). Ein prähistorischer Kultplatz auf Scuol-Motta Sfondraz. Archäol. Dienst Graubünden Denkmalpfl. Graubünden 34-46.

Rehazek A, (2005). Archäozoologie (Frühe Bronzezeit und Schnurkeramik. Conscience 32-37.

Rehazek A (2006) Archäozoologie. Jahrbuch Archäologie Schweiz 89:723

Rehazek A, Schibler J (2012) Archäozoologische Untersuchung der Tierknochen aus der Siedlung des jüngeren Neolithikums von Zug-Vorstadt, Rettungsgrabung 1991. Jahrb Archäol Schweiz 95: $62-67$

Reveillod P, Reverdin L (1927) Les ossementa d'animaux de la station lacustre des Eaux-Vives (Genève Verhandlungen Schweiz). Naturforschenden Ges 108:240

Reynaud Savioz N (2005) La faune. Cah. Archéologie Fribourgeoise 7: 29-37

Rüeger J (1942) Die Tierreste aus der spätbronzezeitlichen Siedlung Crestaulta (Kanton Graubünden) nach den Graubunden 19351938. Rev Suisse Zool 49:251-267

Sakellaridis ME, (1979). The Economic Exploitation of the Swiss Area in the Mesolithic and Neolithic Periods.

Schibler J (1987). Osteoarchäologische Untersuchungen der neolithischen Knochenkomplexe, in: Suter, P.J.Z. "Kleiner H. (Ed.), Tauchgrabungen 1981-1984. Berichte der Zürcher Denkmalpflege, Monographien. Orell Füssli, Zürich, pp. 167-179.

Schibler J, (1996a). Die Tierknochen der Seeufersiedlungen von ZugSumpf und ihre Bedeutung im Rahmen der bronzezeitlichen Wirtschaft im nördlichen Alpenvorland, in: Seifert, M., Jacomet, S., Schibler, J. (Eds.), Die spätbronzezeitlichen Ufersiedlungen von Zug-Sumpf. 1, Die Dorfgeschichte. Kantonales Museum für Urgeschichte, Zug, pp. 305-348. 
Schibler J, (1996b). Archäozoologische Auswertung der Tierknochen, in: Berger L, Brianza M, Gutzwiller P, Joos M, Rentzel P (Eds.), Sondierungen auf dem Wittnauer Horn 1980-1982. Basler Beiträge zur Ur- und Frühgeschichte. Schwabe Verlag, Basel, pp. 71-73.

Schibler J, (1997). Knochen- und Geweihartefakte, in: Schibler, J., Hüster-Plogmann, H., Jacomet, S., Brombacher, C., Gross-Klee, E., Rast-Eicher, A. (Eds.), Ökonomie Und Ökologie Neolithscher Und Bronzezeitlicher Ufersiedlungen Am Zürichsee. Monographien der Kantonsarchäologie Zürich 20, Zürich und Egg, pp. 122-219.

Schibler J, (2001). Glockenbecherzeitliche Tierknochen aus Grube G 211, in: Gnepf Horisberger, U., Hämmerle, S. (Eds.), ChamOberwil, Hof (Kanton Zug). Befunde Und Funde Aus Der Glockenbecherkultur Und Der Bronzezeit., Antiqua. Archäologie Schweiz, Basel, p. 146.

Schibler J (2006) The economy and environment of the 4th and 3rd millennia BC in the northern Alpine foreland based on studies of animal bones. Environ Archaeol 11:49-64

Schibler J (2013) Zooarchaeological data from late Mesolithic and Neolithic sites in Switzerland (CA. 6000-3500 Cal BC). In: Colledge S, Conolly J, Dobney K, Manning K, Shennan S (eds) The Origins and Spread and Spread of Domestic Animals in Southwest Asia and Europe. Left Coast Press Ltd, Walnut Creek, pp 253-269

Schibler J, 2017. Zooarchaeological results from Neolithic and Bronze Age wetland and dryland sites in the Central Alpine Foreland: economic, ecologic, and taphonomic relevance, in: Albarella $\mathrm{U}$, Rizzetto M, Russ H, Vickers K, Viner-Daniels S (Eds.), The Oxford Handbook of Zooarchaeology. Oxford University Press.

Schibler J, Jacomet S (2010) Short climatic fluctuations and their impact on human economies and societies: the potential of the Neolithic lake shore settlements in the Alpine foreland. Environ Archaeol 15: 173-182. https://doi.org/10.1179/146141010X12640787648856

Schibler J, Schäfer M, (2017). Von Hand aufgelesene Tierknochen. Zürich und Egg 2017, 92-127., in: Bleicher C, Harb C (Eds.), Zürich-Parkhaus Opéra. Eine Neolithische Feuchtbodenfundstelle., Monographien Der Kantonsarchäologie Zürich.

Schibler J, Veszeli M, (1998). Neue, stratifizierte Ergebnisse aus neolithischen Seeufersiedlungen von Feldmeilen-Vorderfeld ZH und ihre Bedeutung für die.

Schibler J, Jacomet S, Hüster-Plogmann H, Brombacher C (1997a) Economic Crash in the $37^{\text {th }}$ and $36^{\text {th }}$ Centuries cal BC in Neolithic Lake Shore sites in Switzerland. Anthropozoologica 25-26:553570

Schibler J, Hüster-Plogmann H, Jacomet S, Brombacher C, Gross-Klee E, Rast-Eicher A, (1997b). Ökonomie und Ökologie neolithscher und bronzezeitlicher Ufersiedlungen am Zürichsee. Monographien der Kantonsarchäologie Zürich 20, Zürich und Egg.

Schibler J, Stopp B (1987) Die Stichprobenanalyse des Tierknochenmaterials. In: Zürich Mozartstrasse: Neolithische Und Bronzezeitliche Ufersiedlungen, Berichte Der Zürcher Denkmalpflege, pp 190-197

Schmid E (1952) Die Tierknochen vom Kestenberg, Grabung 1951. UrSchweiz 16(4):96

Simpson G, Roe A, Lewontin R, (1960). Quantitative Zoology, revised edition. Harcourt, Brace, and World, New York.

Spangenberg J, Schibler J, Jacomet S (2006) Chemical analyses of organic residues in archaeological pottery from Arbon Bleiche 3, Switzerland: evidence for dairying in the late Neolithic. J Archaeol Sci 33:113

Stampfli H, (1963). Wisent, Bison bonasus (Linne, 1758), Ur, Bos primigenius Bojanus 1827, und Hausrind, Bos taurus (Linne,
1758), in: Boessneck J, Jequier J-P, Stampfli H (Eds.), Seeburg Burgäschisee-Süd 3. Die Tierreste. Acta Bernensia II, pp. 117-206.

Stampfli HR (1964) Vergleichende Betrachtungen an Tierresten aus zwei neolithischen Ufersiedlungen am Burgäschisee. Mitteilungen Naturforschenden Ges Bern 21:113-136

Stampfli HR (1966) Die Knochenfunde der Grabung Vinelz 1960. Jahrb Bernisch Hist Mus 45:319-320

Stampfli HR (1976a) Die Tierknochen von Egolzwil 5, Osteoarchäologische Untersuchungen. In: Wyss R (ed) Das jungsteinzeitliche Jäger-Bauerndorf von Egolzwil5 im Wauwilermoos. Schweizerisches Landesmuseum Zürich, Zürich, pp 125-140

Stampfli H R, (1976b). Auvernier - La Saunerie nach den Grabungen 1964 und 1965, in: Osteo-Archaeologische Untersuchung Des Tierknochenmaterials Der Spätneolithischen Ufersiedlung. Solothurn (Schweiz).

Stampfli HR (1980) Tierknochenfunde, in: Dokumentation. In: Furger AR (ed) Die Siedlungsreste der Horgener Kultur. Die neolithischen Ufersiedlungen von Twann. Paul Haupt Verlag, Bern, pp 141-160

Stampfli HR, (1992). Die Tierknochen aus den jungsteinzeitlichen Siedlungen Egolzwil 3 und 4. Archäol. Schriften Luzern 1.

Stampfli HR, Hüster Plogmann H, Schibler J, (2003). Viehhaltung und Jagd, in: Zwahlen, H., H. (Eds.), Die jungneolithische Siedlung Port-Stüdeli. Ufersiedlungen am Bielersee. Staatlicher Lehrmittelverlag, Bern, pp. 61-65.

Steppan K (2004) Die Tierknochenfunde aus der Schicht 9 von Sipplingen-Osthafen. Siedlungen Pfyner Kult. Im Osten Pfahlbaubucht Von Sipplingen Bodenseekreis 2:87-96

Steppan K, (2012). Die Tierknochenfunde aus der Seeufersiedlung Bodmann-Weiler II, Kr. Konstanz. Ein Beitrag zu Viehwirtschaft und Jagd der Horgener Kultur am Überlinger See. Hemmenhof. Skripte 7, 55-66.

Stöckli WE, Niffeler U, Gross-Klee E (eds) (1995) Die Schweiz vom Paläolithikum bis zum frühen Mittelalter. Vom Neandertaler bis zu Karl dem Grossen. Verlag Schweizerichte Gesellschaft für Ur- und Frühgeschichte, Basel

Stopp B (1989) Tierknochenauswertung der spätneolithischen Seeufersiedlung Saint-Blaise NE. Universitat Basel

Stopp B (2007) Tierknochen, Zahn- und Geweihfragmente. In: Obrecht J, Gutzwiller P (eds) Die Loppburg- eine befestige Höhensiedlung, Resultate der Ausgrabungen von 2001 in einer vermeintlich mittelalterlichen Burg. Antiqua. Archäologie Schweiz, Basel, pp $119-122$

Studer J (1991) La faune de l'âge de bronze final du site d'HauteriveChampréveyres (Neuchâtel, Suisse). Thèse de 1'Université de Genève, Genève

Teichert M (1984) Size variaton in cattle from Germania Romana andGermania Libera. In: Grigson C, Clutton-Brock J (eds) Animals and Archaeology 4: Husbandry in Europe, 227th edn. BAR InternationalSeries, Oxford, pp 93-103

Trentacoste A, Nieto-Espinet A, Valenzuela-Lamas S (2018) Pre-Roman improvements to agricultural production: Evidence from livestock husbandry in late prehistoric Italy. PLoS One 13:e0208109. https:// doi.org/10.1371/journal.pone.0208109

Tresset A, (2000). Early husbandry in Atlantic areas. Animal introductions, diffusion of techniques and native acculturation at the northwestern margin of Europe, in: Henderson J (Ed.), The Prehistory and Early History of Atlantic Europe, British Archaeological Reports International Series. pp. 17-32.

Valenzuela-Lamas S, Albarella U (2017) Animal Husbandry across the Western Roman Empire: Changes and Continuities. Eur J Archaeol 20:402-415. https://doi.org/10.1017/eaa.2017.22 
Vellart I, Fischer M, (2006). Die Tierknochen der Rettungsgrabungen 1988 - 91. Archäol. Steinhausen, Sennweid“ Kanton Zug Ergeb. Untersuchungen Von 1942 41, 292-203.

Veszeli, M., (2001). Restliche Tierknochen aus der Siedlung, in: Gnepf Horisberger, U., Hämmerle, S. (Eds.), Cham-Oberwil, Hof (Kanton Zug). Befunde Und Funde Aus Der Glockenbecherkultur Und Der Bronzezeit, Antiqua. Archäologie Schweiz, Basel, pp. 146-149.

Veszeli M, Hüster Plogmann H, (2007). Die Tierknochen, in: Eberschweiler B, Riethmann P, Ruoff U (Eds.), Das spätbronzezeitliche Dorf von Greifensee-Böschen, Dorfgeschichte, Hausstrukturen und Fundmaterial. Monographien der Kantonsarchäologie. Fotorotar, Zürich und Egg, pp. 232-234.

Vigne J-D (1988) Les Mammifères post-glaciaires de Corse, étude Archéozoologique (XXVIe supplement aé Gallia Préhistoire). Éditions du Centre National de la Recherche Scientifique, Paris

von den Driesch A, (1976). A guide to the measurement of animal bones from archaeological sites. Harvard University.

von den Driesch A, and J Boessneck. (1976) 'Die Fauna Vom Castro Do Zambujal (Fundmaterial Der Grabungen von 1966 Bis 1973 Mit Ausnahme Der Zwingerfunde).' In Studien Über Frühe Tierknochenfunde von Der Iberischen Halbinsel 5, 4-129. München, Madrid: Institut für Palaeoanatomie, Domestikationsforschung und Geschichte der Tiermedizin der
Universität München. Deutsches Archäologisches Institut Abteilung Madrid

Wettstein E (1924) Die Tierreste aus dem Pfahlbau am Alpenquai in Zürich. Vierteljahrsschr Naturforschenden Ges Zür 69:78-127

Wickham H (2007) Reshaping Data with the reshape Package. J Stat Softw 21(12):1-20 URL http://www.jstatsoft.org/v21/i12/

Wickham H (2016). ggplot2: Elegant Graphics for Data Analysis. Springer-Verlag New York.

Wickham H, François R, Henry L and Müller K (2020). dplyr: A Grammar of Data Manipulation. R package version 1.0.2. https:// CRAN.R-project.org/package=dplyr.

Wright E (2016) The Morphological Variability of the European Aurochs from the Middle Pleistocene to Its Extinction: A Zooarchaeological Study. British Archaeological Reports International Series 2815.

Wright E, Schäfer M, Stopp B, Marti-Grädel E, Kerdy M, Deschler-Erb S, Schibler J (2020) Neolithic and Bronze Age cattle data from Switzerland. Open Context. https://doi.org/10.6078/M7H13049

Würgler F (1956) Beitrag zur Kenntnis der mittelalterlichen Fauna der Schweiz. Burgstellen: Iddaburg, Clanx, Hohensax, Starkenstein. Jahrb St Gall Naturwissenschaftlichen Ges 75:1-90

Publisher's note Springer Nature remains neutral with regard to jurisdictional claims in published maps and institutional affiliations. 